Portland State University

PDXScholar

$11-24-1976$

\title{
An Aspect of the Process of School Desegregation: the Effects of Reading Ability Grouping on Social Attractiveness and Peer-Perceived Success
}

David A. Johnson

Portland State University

Follow this and additional works at: https://pdxscholar.library.pdx.edu/open_access_etds

Part of the Educational Sociology Commons

Let us know how access to this document benefits you.

\section{Recommended Citation}

Johnson, David A., "An Aspect of the Process of School Desegregation: the Effects of Reading Ability Grouping on Social Attractiveness and Peer-Perceived Success" (1976). Dissertations and Theses. Paper 2594.

https://doi.org/10.15760/etd.2591

This Thesis is brought to you for free and open access. It has been accepted for inclusion in Dissertations and Theses by an authorized administrator of PDXScholar. Please contact us if we can make this document more accessible: pdxscholar@pdx.edu. 
AN ABSTRACT OF THE THESIS OF David A. Johnson for the Master of Science in Sociology presented November 24, 1976.

Title: An Aspect of the Process of School Desegregation: The Effects of Reading Ability Grouping on Social Attractiveness and Peer-Perceived Success

APPROVED BY MEMBERS OF THE THESIS COMMITTEE:

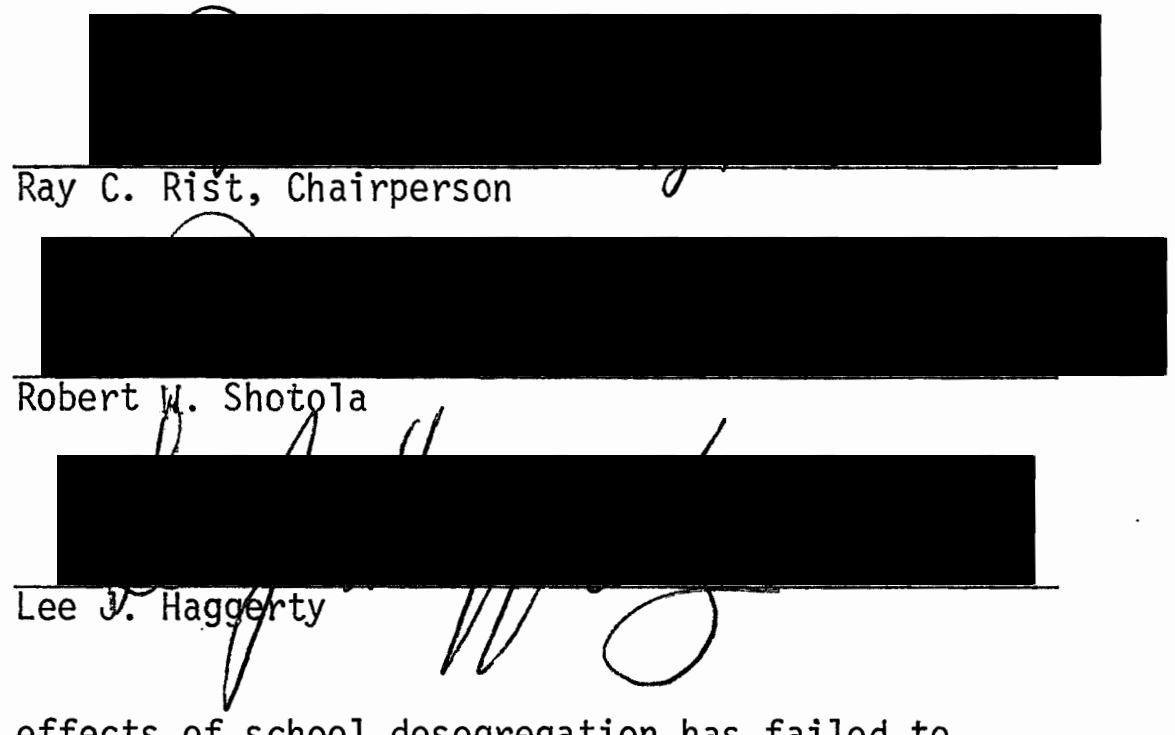

Research on the effects of school desegregation has failed to produce conclusive findings. An over emphas is on the outcomes of school desegregation, usually assessed through the use of standardized test scores, has created a situation in which there exists a paucity of studies of the day-to-day process of school desegregation: instructional practices, student interaction, and teacher behavior in the classroom. More research on the process of school desegregation is needed if its results or outcomes are to become more interpretabie. 
This thesis focuses on one aspect of the process of school desegregation. The practice of reading ability grouping was examined for its effect on the social attractiveness and peer image of success, of students in three minimally desegregated elementary classrooms. Both qualitative (non-participant observations) and quantitative (sociometric questionnaire) approaches were used to ascertain whether there was a relationship between reading group placement and a student's social attractiveness among his or her peers, and between reading group placement and a student's image (among his or her peers) of success. Particular attention was paid to the ways in which group membership affected the social attractiveness and image of success of the few black students in the predominantly white classes. Data were gathered over the period of one school year (1973-1974), in two third grade classrooms and one fourth grade room.

The practice of reading ability grouping, in the three classrooms studied, involved distinctive routines and differential behaviors on the part of the students and teachers. Differential attention on the part of the teachers and a differential opportunity for gaining peer attention among the students, appeared to create a situation in which students assigned to the higher reading groups were more likely to be socially attractive, and to be perceived by their peers as successful, than students in the lower reading groups. However, the sociometric data offered onty partial verification of this observation.

Early in the school year (November) reading group membership accounted for on $7 y 14$ percent of the variation in social attractiveness 
in these three classrooms (the higher the reading group, the greater the student's social attractiveness). This relationship was even weaker in the spring, with reading group membership accounting for only five percent of the variation in social attractiveness among students. The strongest relationship between reading group membership and social attractiveness was found in the fourth grade classroom $\left(r^{2}=.22\right)$.

The relationship between reading group membership and peerperceived success was somewhat stronger. In both the fall and spring, reading group membership accounted for 29 percent of the variation in peer-perceived success among students in these three classrooms (the higher the reading group, the greater the perceived success). The strongest relationship between reading group membership and peerperceived success also was found in the fourth grade $\left(r^{2}=.45\right)$.

In general, these results indicate that the practice of reading ability grouping makes a definite contribution to a student's image (among his or her peers) of success in the classroom. All of the black students were members of the lowest reading groups in their respective classrooms. By the spring, all of the black students had negative peer-perceived success scores (i.e., they were perceived by their fellow students as doing poorly in school). The practice of reading ability grouping can thus be viewed as contributing to an image of failure among black students in desegregated classrooms. Consequently, the presence or absence of reading ability grouping in desegregated classrooms can be thought of as determining, to some extent, the outcomes of the desegregation process. 
AN ASPECT OF THE PROCESS OF SCHOOL DESEGREGATION:

THE EFFECTS OF READING ABILITY GROUPING

ON SOCIAL ATTRACTIVENESS AND

PEER-PERCEIVED SUCCESS

by

DAVID A. JOHNSON

A thesis submitted in partial fulfillment of the

requirements for the degree of

MASTER OF SCIENCE
in
SOCIOLOGY

Portland State University

1976 
TO THE OFFICE OF GRADUATE STUDIES AND RESEARCH:

The members of the Committee approve the thesis of David A. Johnson presented November 24, 1976.

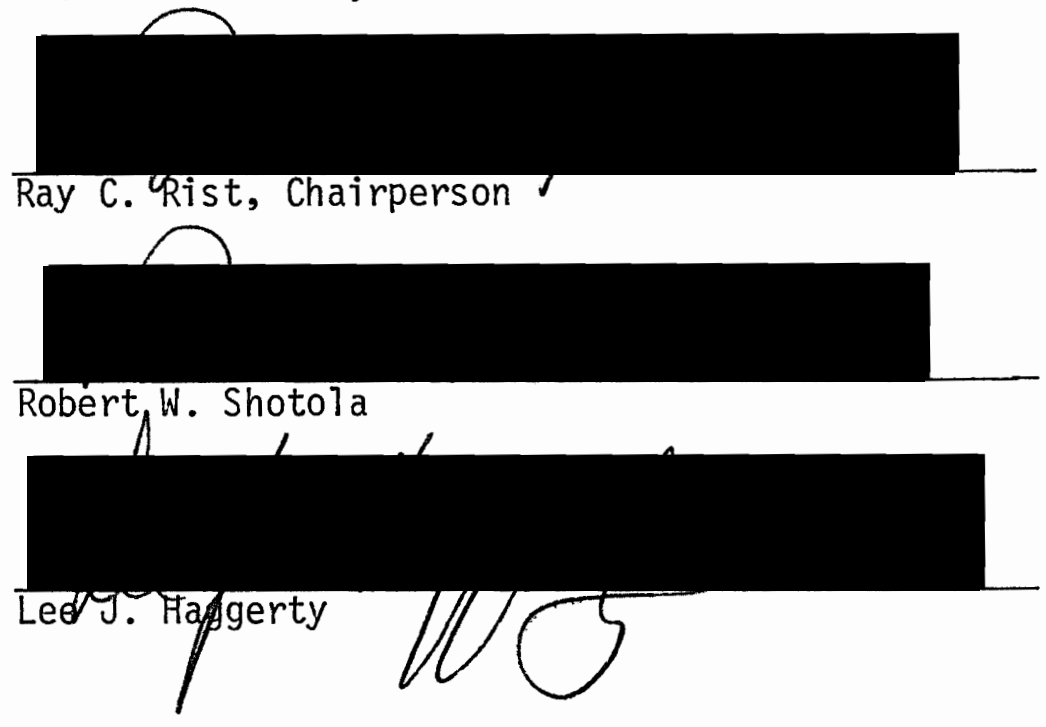

APPROVED:

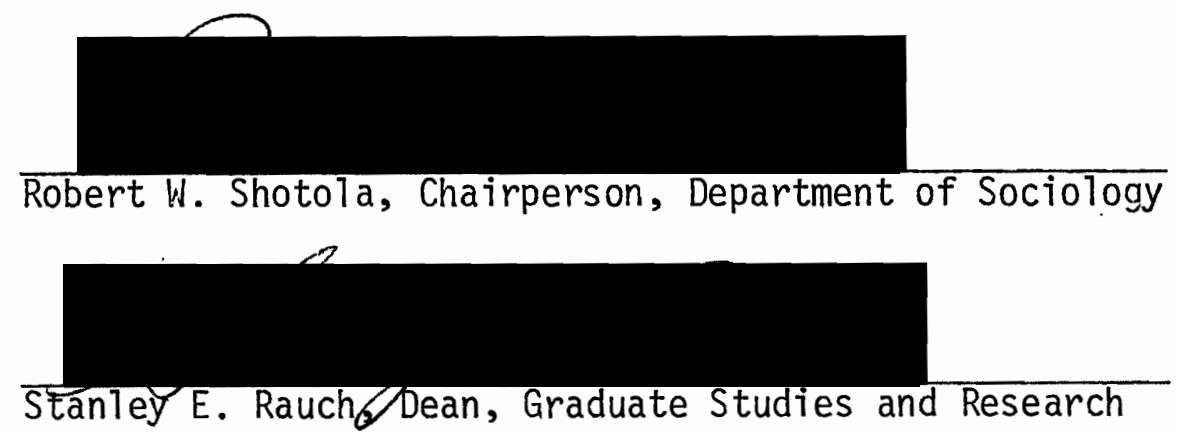




\section{ACKNOWLEDGMENTS}

This thesis was a long time in the making. The background research, data collection, and data analys is span the course of three years. During those three years a number of people contributed to my efforts by expressing interest in my work and encouraging me to press on. The following are but a few of the many people who in some way contributed to my work.

First, I'd like to thank Ray Rist for giving me the initial opportunity to work in the area of school desegregation. Second, I wish to express a deep gratitude to the students and teachers who were the subjects of my study. Without their patience this study would have never taken place. The three teachers I worked with are a credit to their profession and I regard them with the utmost respect. I thank the students for being themselves, for pulling at my beard and accepting me as part of their classroom.

During the off and on periods of data analysis and writing there were some special people who from time to time shared a beer with me while I talked about some aspect of the write up. I want to thank John Savage, Chris Nelson, Carole Caldwell, and Carole Holland for a listening ear and quiet encouragement from time to time.

I'm grateful to Lee Haggerty for helping me see the thes is through to completion. I want to especially thank Bob Shotola for his constructive 
criticism of the first draft and guiding feedback on the second draft. I want to also thank Kathy Grove for proofreading and typing the final draft. It makes it a lot easier when you have a person of her quality typing the final draft.

Finally, I'd like to thank Marla Brassard for her friendship during the writing of the second draft. It was nice to have someone who could relate to the time and energy involved in a research project that had gone on for three years.

Rocky

October, 1976 
TABLE OF CONTENTS

PAGE

ACKNOWLEDGMENTS

LIST OF TABLES

viii

\section{CHAPTER}

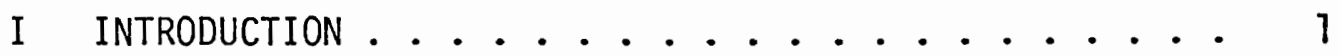

Two Areas of Research Which Bear on the

Process of school Desegregation ....... 4

Necessary Conditions

Educational Practices that Contribute to

Failure Among Black Students

II PROBLEM: LACK OF RESEARCH ON THE PROCESS OF READING

ABILITY GROUPING IN DESEGREGATED CLASSROOMS .... 10

The Need for Research on the Process of Ability

Grouping. .............. 10

Ability Grouping Within the Classroom

The Present Study: Reading Ability Grouping and

Desegregated $\mathrm{Cl}$ assrooms ........ 13

III THE SETTING FOR THE STUDY . . . . . . . . 15

IV METHODOLOGY .................. 20

Observationat Methods ......... 20

Interview Methods .......... 22

Quantative Methods ........... 24 
Third Grade Number One

Third Grade Number Two

Fourth Grade

Reading Group Assignment Procedures .... . . . 29

The Routine of Reading Ability Grouping . . . . 30

Third Grade Number One

Third Grade Number Two

Fourth Grade

Differential Behavior Associated With Reading

Ability Grouping ........... 33

Third Grade Number One

Third Grade Number Two

Fourth Grade

Social Cohesion Among Reading Groups . . . . 39

Third Grade Number One

Third Grade Number Two

Fourth Grade

Quantitative Data ............. 43

Reading Group Membership and Social Attractiveness

Other Variables Associated With Social

Attractiveness in the Classroom

Social Cohesiveness Withing Reading Groups . . . 49

Sumnary ................. 51 
VI READING GROUP MEMBERSHIP AND PEER PERCEIVED SUCCESS . • 55

The Routine and Differential Learning Activities

Associated With Reading Ability Grouping . . . . 55

Quantitative Data ......... 56

Summary .................. 59

VII READING ABILITY GROUPING AND SCHOOL DESEGREGATION:

SOCIAL ATTRACTIVENESS AND IMAGE OF SUCCESS AMONG BLACK STUDENTS

Reading Ability Grouping and the Social Attractiveness

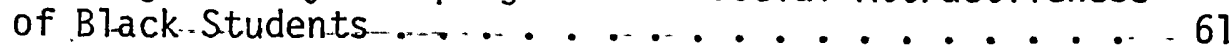

Third Grade Number One

Third Grade Number Two

Fourth Grade

Summary

Reading Ability Grouping and Image of Success

Among Black Students

Third Grade Number One

Third Grade Number Two

Fourth Grade

Summary . . . . . . . . . . . 78

VIII SUMMARY ............................. 81

SELECTED REFERENCES ................. 86

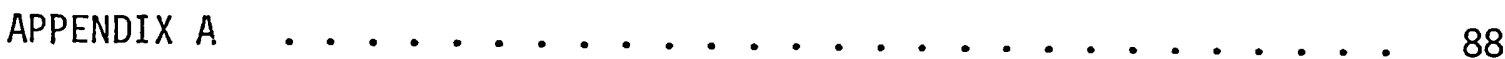

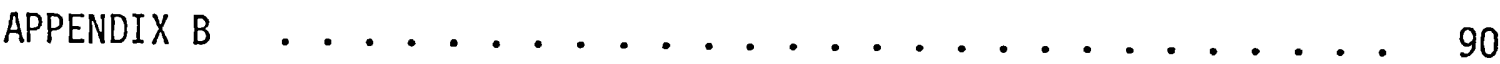




\section{LIST OF TABLES}

TABLE

PAGE

I Comparative Socioeconomic Factors for Garland and

the Schools From Which the Black Students

Were Bused ............. 17

II Comparative Test Data for Garland and Schools From

Which Black Students Were Bused . . . . . 18

II Correlations Between Reading Group Membership and

Social Attractiveness ........... 44

IV The Effect of Gender on Seatmate Selections . . . . 46

$V$ The Effect of Gender on Seatmate Rejections . . . . 48

VI Reading Group Cohesiveness: Direct Probabilities

of First Seatmate Selections ........ 50

Continued on Page ........... 52

VII Correlations Between Reading Group Membership and

Peer-Perceived Success . . . . . . . 57

VIII Social Attraction Scores By Reading Group: Third

Grade Number One .......... 63

IX Social Attraction Scores By Reading Group: Third

Grade Number Two .......... . 66

$X$ Social Attractiveness Scores By Reading Group:

Fourth Grade .............. . . 69 
XI Peer-Perceived Success Scores By Reading Group:

Third Grade Number One . . . . . . . . 75

XII Peer-Perceived Success Scores:By. Reading Group:

Third Grade Number Two . . . . . . . . . 77

XIII Peer-Perceived Success Scores By Reading Group:

Fourth Grade ............. . 79 


\section{CHAPTER I}

\section{IATTRODUCTION}

It has been over twenty years since the Tandmark Supreme Court case of Brown vs. Board of Education. The thrust of that decision was a recognition that the segregation of black students within a school system was a contributing factor to their high rate of academic failure. ${ }^{1}$ As a result of this recognition, school desegregation was initiated and continues to proceed amid wide spread controversy. Moreover, far from subsiding, it appears as though the controversy over whether or not school districts should be racially desegregated continues to rage and promises to remain for some time to come.

The divisiveness surrounding the issue of school desegregation has been fostered, in part, by the failure of the social sciences to offer conclusive evidence about the effects of school desegregation. In a recent review of the literature on the outcomes of desegregation, Nancy St. John (1975) remarked:

In sum, adequate data have not yet been gathered to determine a causal relationship between school racial composition and academic achievement. More than a decade of considerable research effort has produced no definite positive findings. In view of the political, moral, and technical difficulties of investigation on this question, it

1

See Supreme Court Decision, Brown vs. Board of Education (1954), footnote number three. 
is doubtful that all the canons of the scientific method will ever be met or a causal relationship ever estab7ished.

(St. John, 1975:36)

St. John was also inconclusive regarding the effects of school desegregation on black self-esteem and racial prejudice.

Part of the reason for the failure of the social sciences to provide much clarity about this issue stems not from political, moral, or technical difficulties, but rather from a tendency to focus on the results of school desegregation (i.e., achievement scores, self-esteem scores, and racial attitude scores) and ignore the process and conditions associated with it ${ }^{2}$ (Carithers, 1970; St. John; 1975; Johnson, 1976). The lack of definition and understanding regarding the process of school desegregation makes it impossible to interpret the conflicting outcomes of school desegregation.

The importance of understanding and identifying the process or conditions of interracial contact was first noted in the work of Allport (1954). Although Allport did not explicitly address the issue of school desegregation, his writings on interracial contact emphasized the nature (process and conditions) of contact as being crucial. Allport stated that interracial contact per se could have many different outcomes and should not be considered as generally resulting in positive results:

\section{2}

By process and conditions I am referring to the day-to-day social interaction between students and teachers, students and students, teachers and teachers, and the organized learning activities around which such social interaction occurs. 
It has sometimes been held that merely by assembling people without regard for race, color, religion, or national origin, we can thereby destroy stereotypes and develop friendly attitudes. This is simply not the case. (Allport, 1954:261)

Al1port (1954) went on to say that one has to consider a number of variables before-speculating on the outcome of interracial contact. He mentioned the respective statuses of the minority and majority groups, the amount of contact, the social atmosphere in which the contact takes place, and the personalities involved, as being influential in determining the outcome of interracial contact. Generally speaking, Allport believed that equal status contact was... a-prerequisite for reducing feelings of inferiority on the part of blacks.

Prejudice (unless deeply rooted in the character structure of the individual) may be reduced by equal status contact between majority and minority groups in the pursuit of common goals. (A11port, 1954:281) (emphasis added)

Since the publication of Allport's work, a number of studies have confirmed that interracial mixing, by itself, will not lessen feelings of inferiority among black students (Bronfenbrenner, 1967; Anderson, 1967; Amir, 1969; Carithers, 1970; Armor, 1972; St. John, 1975). In a review of sixteen years of research on school desegregation and racial cleavage, Carithers (1970) reported conflicting results. In some studies she found that interracial contact enhanced interracial acceptance, lessened prejudice, and raised the self-esteem of black students. In other studies she found the direct opposites. Carithers was unable to interpret these mixed findings because the studies she reviewed failed to identify clearly the situation within which the interracial contact took place. This neglect of the process of interracial contact made it 
impossible for her to explain the discrepant findings: "We simply do not know what happens to whom under what conditions." (Carithers, 1970:43)

A more recent review of the literature on school desegregation reasserts the need for studies that focus on the process rather than the results of school desegregation. After reviewing 120 studies, St. John (1975) concluded that the greatest need is for small scale studies that identify the process of interracial schooling in different school settings:

At this juncture further investigation of the broad question--Does desegregation benefit children?--would seem a poor use of national resources. The pressing need now is to discover the school conditions under which the benefits of mixed schooling are maximized and its hardships minimized.

The most needed type of research at this juncture is probably not a mammoth longitudinal testing program with measurements on dozens of background variables to allow exquisite statistical manipulations. True, if the right variables were measured and measured well, the results might be very interesting. But far more illuminating would be small-scale studies involving anthropological observations of the process of interracial schooling, across settings diverse in black/white ratios and in middle class/lower-class ratios, and also diverse in their educational philosophies and techniques. (St. John, 1975:122), emphasis added)

TWO AREAS OF RESEARCH WHICH BEAR ON THE PROCESS OF SCHOOL DESEGREGATION

To date, two different areas of research have developed information relevant to the process of school desegregation. The first attempts to specify the conditions that are necessary for the process of school desegregation to result in the desired goals (i.e., rise in black 
achievement and selfmesteem and improved racial attitudes). The second area of research focuses on identifying educational practices (processes) that contribute to high rates of failure among black students.

\section{Necessary Conditions}

An example of the first approach is Pearl's (1972) attempt to specify the conditions that are necessary for the process of school desegregation to bring about positive results. He argued that if the staff and curriculum of a desegregated school are integrated, educational gains among black students will occur. More precise examples of this kind of research are found in the literature regarding experimentally induced educational processes. Cohen and Roper (1972) achieved some success in experimentally creating a condition of equal status among black and white students in the same classroom. Black students were taken out of the classroom and taught how to construct a two-transistor radio. These black students then returned to the classroom and taught the white students how to build the radio. After this experimental treatment, the black students initiated more conversation and were listened to more by white students during group learning situations than they had been before.

Aronson, et. al., (1975) also reported success in experimentally creating conditions of equal status in desegregated classrooms. In Aronson's study, individual members of a biracial task group were each given a section of a story or lesson the group was to learn as a whole. After studying their respective parts, the students met in a group and questioned each other in order to learn the whole story or lesson. This 
created a condition where knowledge had to. be demonstrated by each member of the biracial group in order for any one member to learn the lesson. This process resulted in a situation where the black students spoke up and were listened to just as much as white students during learning situations.

It should be noted here that the educational schemes (processes) employed by Cohen and Roper and by Aronson are uncommon to public education and certainly not found in most cases of school desegregation. For example, Cohen and Roper (1973) had small biracial groups work together in solving problems. Students in these groups were evaluated as a group: there was no individual evaluation. Cooperative criterion situations like this are rare in most institutions of public education, which typically utilize rewards based on competitive individual performances.

Educational Practices that Contribute to Failure Among Black Students

The second area of research bearing on the process of school desegregation involves the identification of educational practices (process of education) that contribute to the perceived failure of black students. For example, standardized achievement and intelligence tests are an integral part of the educational process. These tests are used by teachers and administrators to assess academic gains among students. More importantly however, these tests are used by teachers in the assignment of students to different ability. groups and curriculum tracks (Pearl, 1972). Test results are also used by guidance counselors in advising students about their future plans (Schafer and 0leza, 1971). 
In recent years there has been a growth in concern about inherent biases in standardized tests. Jencks (1972) has pointed out a number of class/racial biases contained in most standardized tests. These tests were composed by white middle-class psychologists and consequently reflect a world view that is particular to white middle-class society. This monocultural orientation places non-white and lower-class students at a disadvantage. For example, standardized tests often contain questions regarding miscellaneous bits of information common to the media and day-to-day life of white middle-class students but foreign to nonwhite or lower-class students. These tests also measure a peculiar form of motivation. Often no realistic reason is given students for completing standardized achievement tests. Many times a student never finds out how he/she did on the test. Taking a test for the sake of taking a test may make sense for a middle-class student whose parents emphasize the importance of tests. However, a non-white or lower-class student may lack such motivation. Perceived educational inferiority among black students, therefore, may be due in part to the practice of standardized testing.

As mentioned above, the use of standardized testing is related to ability grouping and curriculum tracking. Ability grouping and curriculum tracking pertain to the organization of instructional groups on the basis of students'. similarity on one or more characteristics. One of the more common characteristics used is performance on standardized tests. Other characteristics include past academic performance and teacher perceptions of student potential. The origins of homogeneous ability grouping can be traced to the beginnings of public education 
during the 19th century (N.E.A., 1968:11). The practice of ability grouping appears to be widespread in America. A survey taken during the school year 1958-59 showed that nearly 78 percent of urban school districts (school districts with a student population of 2,000 or more) in this country practiced some form of ability grouping for instructional purposes (N.E.A., 1961:18-19). More recent surveys indicate that ability grouping on a national level is becoming more and more prevalent and this trend is likely to continue (Esposito, 1975:177). Recent reviews of research on the effects of ability grouping and curriculum tracking on achievement scores (Findley and Bryan, 1971; Esposito, 1973) indicate the following: (1) There is conflicting evidence regarding the effects of ability grouping and tracking on scholastic achievement in the higher ability groups and tracksi. Studies comparing matched heterogeneous and homogeneous ability groups have in some cases revealed no significant differences in achievement test scores and in others showed significant differences in favor of the homogeneous ability groups and tracks. (2) With respect to middle tracks and ability groups, homogeneous ability grouping and curriculum tracking make no difference in achievement test scores when compared with heterogeneous grouping. (3) Compared with heterogeneous instruction, the research indicates that ability grouping and curriculum tracking almost uniformly depress the achievement test scores of students in the lowest ability groups and tracks. In short, among studies showing ability grouping to have significant pedagogical effects, the results indicate that achievement in the higher groups may be increased while achievement in the lower groups is depressed. 
The fact that ability grouping and curriculum tracking tend to inhibit academic achievement in the lower groups has implications for school desegregation when coupled with findings that black students are disproportionately assigned to the lower groups (Kariger, 1963; Meh1, 1967; and Mackler, 1969). For example, a U.S. Civil Rights Commission study of St. Louis Public Schools found that "a disproportionate percentage of students in track I (the highest track) were white and a similar disproportion in track III (the lowest track) were black" (Civil Rights Commission, 1962:292). Thus, it appears that ability grouping and curriculum tracking constitute educational processes that have a bearing on the outcomes of school desegregation. 
CHAPTER II

PROBLEM: LACK OF RESEARCH ON THE PROCESS OF READING ABILITY GROUPING .IN . DESEGREGATED CLASSROOMS

THE NEED FOR RESEARCH ON THE PROCESS OF ABILITY GROUPING

As has research on school desegregation, research on ability grouping has concentrated on its outcomes (i.e., achievement scores) and ignored the social behaviors that accompany it (Wilson and Ribovich, 1973; Esposito, 1973). Relevant social behaviors include social interaction between students and between teacher and students that occurs in relation to the practice of ability grouping. After surveying the literature on ability grouping, Esposito noted:

The literature on ability grouping is replete with studies which attempt to investigate or demonstrate the extent to which a single variable or combination of variables descriptive of children at a specific point in time (e.g., intelligence, reading level, self-image, arithmetic level, etc.) affects or is related to subsequent performance on academic and/or social dimensions. However, there exists a paucity of studies which seek to investigate and explain in what ways and to what extent the structural properties of the grouping schemes influence program conditions, so as to cultivate or discourage patterns of teacher-student interaction. (Esposito, 1973:172-173)

\section{Ability Grouping Within The Classroom}

Although much research has been concerned with the effects of ability grouping, most of the work has been on between classroom ability grouping in the upper-elementary and secondary grades (Findley and Bryan, 1975; Schafer and 01exa, 1971; Esposito, 1973). Few studies 
have examined the effects of ability grouping within the classroom.

Perhaps the most common form of ability grouping within the classroom is reading ability grouping. Available figures indicate that reading ability grouping within classrooms is a popular form of homogeneous Igrouping in the lower elementary grade levels. In a national survey, Austin and Morris (1963:265) found that over 85 percent of eiementary schools surveyed reported that they always or often employ reading ability grouping for instructional purposes. Other studies have supported this finding (Smith, 1971).

The only studies, to date, that relate somewhat to the process of reading ability grouping are those of McGinley and McGinley (1970) and Rist (1974). McGinley and McGinley examined the effect of reading ability grouping on social cohesion within the various reading groups. They asked first grade students (in six different classrooms) what three children in the classroom they would like to work with. The results were that members of the highest reading groups were chosen more frequently than would be expected by chance. ${ }^{1}$ McGinley and McGinley also found that students in the highest reading groups tended to choose students from their own group more than would be expected by chance while students in the lower reading groups exhibited no such within group preference in

1 McGinley and McGinley misused chi-square in analyzing their data. In applying chi-square to second and third choices of the students, McGinley and McGinley violate the assumption of independence. The second and third choices are not independent, but dependent on the first choice. 
their choices. McGinley and McGinley concluded that reading ability grouping stimulated social cohesion in the highest reading groups while discouraging it in the lower reading groups.

Rist (1974) focused on reading ability grouping in a three-year longitudinal study of a predominantly black school in St. Louis, Missouri. He followed a group of black students from kindergarten through the second grade. Based on non-participant classroom observations, Rist described how membership in a particular reading group was associated with social status in the classroom. Students who were members of the highest reading group all sat together at the same table and enjoyed high status, while the rest of the class occupied a lower social position. Students who were in the lower reading groups received less attention and more ridicule from the teacher. They also were looked down upon by members of the first reading group. ATthough reading ability grouping seemed to be important in determining academic competence in Rist's study, its influence appears to have been secondary to socioeconomic background. Rist reported that teachers expected high achievement from middle-class children. Consequently, students with middle-class backgrounds were assigned to the highest reading group while students from lower-class backgrounds filled in the ranks of the lower reading groups. In this case, social-class background apparently predetermined reading group membership and social status in the classroom. Rist's study indicated that reading ability grouping creates a kind of caste system in the classroom. It provides a social structure that produces feelings of inferiority and failure among students in the 
lower reading groups and enhances feelings of competence in students who are members of the highest reading group. Furthermore, Rist observed that students in the highest reading group view themselves as separate from the other students.

Although the studies mentioned shed some light on the social processes associated with reading ability grouping, they provide an incomplete picture. The major focus of Rist's study was the differential treatment of students based on socioeconomic background and not the process of reading ability grouping. Indeed, reading ability grouping might have been of no consequence in determining the social climate that Rist depicted. McGinley and McGinley did not describe how reading ability grouping affected social cohesion in the classrooms from which they obtained their data. They merely reported the results of the sociometric questionnaire they administered and speculated on possible explanations for their findings.

THE PRESENT STUDY: READING ABILITY GROUPING AND DESEGREGATED CLASSROOMS

The social processes associated with reading ability grouping remain to be studied in the context of desegregated classrooms. Rist's (1974) study took place in a segregated urban black school in St. Louis; McGinley and McGinley (1970) failed to specify the racial composition of the classrooms from which they obtained their data. In his review of the literature on ability grouping, Esposito (1973) emphasized the need for research on ability grouping within the context of school desegregation: 
A careful review of ability grouping research indicates that few studies have considered the educational relevance of ethnic and socioeconomic status in the placement of children into ability groups or curricular tracts and that few have examined the social, economic, and political consequences of grouping schemes with respect to ethnic and socioeconomic separation of children. . .

Not withstanding the retative absence of studies devoted to these problem areas, however, and given a continued national effort to desegregate public schools, existing data bearing on the relationship between ability grouping and de facto segregation in the public school classroom should be reviewed and interpreted in the interest of promoting the principle of equal opportunity. (Esposito, 1973:164)

The present study focused on the practice of reading ability grouping as it occurs within the context of desegregated classrooms. An attempt was made to describe the social processes ${ }^{2}$ that accompany reading ability grouping in the particular setting of a few desegregated classrooms. Specific attention was given the following: (1) verification of the findings of McGinley and McGinley (1970) and Rist (1974), (2) a critical examination of the strength of association between reading ability group membership and social attractiveness in the classroom, (3) a critical examination of the strength of association between reading ability group membership and being perceived as a success or failure in the classroom, and (4) an examination of the effects of reading ability grouping on the social attractiveness of black students and their image of competence.

2

By social process I am referring to the interaction between teacher and students, students and students, and teachers and teachers. 
CHAPTER III

\section{THE SETTING FOR THE STUDY}

In Portland, Oregon, there is currently (1976) a voluntary busing program whereby black students each day leave the predominantly black cormunity to attend predominantly white schools on a "space available" basis. White students are not bused into the black community. Not all white schools receive the same number of black students; some receive as few as 3 , others as many as 49 . This results in varying racial compositions among the desegregated schools. The percentage of black students in these schoo7.s ranges from 1.4 percent to 10.4 percent, with an average of 6.7 percent (Portland Public School District, 1973). The site for the present study was Garland school. ' Garland is an elementary (grades one through eight) school located in an uppermiddle class neighborhood of Portland. In 1973, the median annual family income of the neighborhood surrounding Garland was over $\$ 16,000$. During the school year 1973-74, Garland had an enroliment of about 650 pupils. At the time of this study Garland was undergoing its first year of desegregation. Of the school's total enrollment, 19 or 3 percent were black students who were part of the school district's voluntary busing program.

The name of the school is a pseadonym. 
As mentioned earlier; there is a need for research on the process of school desegregation as it occurs in a number of different settings. The low proportion of black students at Garland, and Portland's desegregated schools in general, should in no way reduce the relative significance of data from Garland. As emphasized earlier, recent reviews of the literature indicate that data on the day to day process of desegregation is needed from a number of different settings. Consequently, concern for an appropriate racial composition is of secondary importance:

Nevertheless, I have come slowly to the conclusion that the overall inconclusiveness of the findings is due not so much to these limitations (i.e., methodological limitations) as to the fallacious assumption that desegregation is a unitary phenomenon, that racial balance is the important variable, and that how it is implemented is of secondary importance. (St. John, 1975:11) (parenthes is added)

The black students at Garland were bused from three different schools. The median annual family income of students attending these three schools was less than $\$ 6,500$ in 1973 . The average student achievement level at Garland (before the black students were bused in) was rated in the upper 80th percentile compared with the other elementary schools in the Portland School District, while the average achievement level of the three schools from which the black students were bused ranked in the lower 20th percentile. Garland and the schools from which the black students were bused are compared on the basis of socioeconomic and scholastic factors in tables I and II.

The preceding comparisons indicate that Garland represents a case of minimal (few black students) desegregation where there exists marked 
TABLE I

COMPARATIVE SOCIOECONOMIC FACTORS FOR GARLAND

AND THE SCHOOLS FROM WHICH THE BLACK

STUDENTS WERE BUSED*

Garland

Schools from which black students were bused

Median family income of students

$\$ 16,000 * *$

$\$ 6,500$

Students with annual

family incomes

under $\$ 4,000$

$7 \%$

$27 \%$

Percentage of students

with family on

welfare

$2 \%$

$61 \%$

* Portland Public School District Figures (1973)

** These figures are rounded. 


\section{TABLE II}

\section{COMPARATIVE TEST DATA FOR GARLAND AND SCHOOLS \\ FROM WHICH BLACK STUDENTS WERE BUSED* \\ (fourth grade averages)}

\begin{tabular}{|c|c|c|}
\hline & Garland & were bused \\
\hline Reading & $\begin{array}{l}\text { average score in } \\
\text { 80th percentile }\end{array}$ & $\begin{array}{l}\text { average score in } \\
\text { 20th percentile }\end{array}$ \\
\hline Math Concepts & $\begin{array}{l}\text { average score in } \\
\text { 80th percentile }\end{array}$ & $\begin{array}{l}\text { average score in } \\
\text { loth percentile }\end{array}$ \\
\hline Math Problem Solving & $\begin{array}{l}\text { average score in } \\
\text { 80th percentile }\end{array}$ & $\begin{array}{l}\text { average score in } \\
\text { 20th percentile }\end{array}$ \\
\hline Math Computation & $\begin{array}{l}\text { average score in } \\
\text { 80th percentile }\end{array}$ & $\begin{array}{l}\text { average score in } \\
\text { loth percentile }\end{array}$ \\
\hline Math Total & $\begin{array}{l}\text { average score in } \\
\text { 80th percentile }\end{array}$ & $\begin{array}{l}\text { average score in } \\
\text { loth percentile }\end{array}$ \\
\hline
\end{tabular}

* Portland Public School District Figures (1973)

** These figures indicate the academic achievement levels at Garland and the schools from which the black.students were bused relative to other Portland Schools. For example, the average fourth grade reading score at Garland ranks in the 80th percentile of. all Portland schools while the same score for the black schools ranks in the lower 10 percent of all Portland schools. 
differences in social class and achievement levels. between.black and white students. It is important to keep thïs context in mind while considering the data reported in this study. 
CHAPTER IV

METHODOLOGY

\section{OBSERVATIONAL METHODS}

In September of 1973 I gained access to Garland School for the purpose of making classroom observations. Initially these observations took no specific focus, other than to observe the desegregation process as it took place at this particular school. By October it became apparent that because of time limitations it would be possible to observe only a few classrooms. At that time three classrooms were selected in which I had established a comfortable rapport with the teachers and in which the number of black students varied slightly: (1) A third grade classroom (third grade number one) which numbered 26 students (10 females and 16 males). ${ }^{1}$ There was one black male student in this class. (2) A third grade classroom (third grade number two) that numbered 25 students ( 12 females and 13 males). ${ }^{2}$ There were two black males in this classroom. (3) A fourth grade classroom which numbered 28 students ( 11 females and 17 males). ${ }^{3}$ Two black male students and one black female student were in this class.

\section{1}

In the spring there were 11 females and 14 males, see Chapter VII. 2 .

In the spring there were 12 females and 14 males, see Chapter VII. 3

In the spring there were 11 females and 76 males. Also, one of the black male students had moved to another school, see Chapter VII. 
Beginning in October; each classroom was observed at least once a week during the course of the school year; 4 for a period of time ranging from 30 minutes to one hour. Students in these three classrooms were observed at recess and lunch as well as in the classroom. Throughout the year, observations were made at different times of the day in an attempt to gain a representative sample of classroom activities.

The methodology employed in these observations has been refered to by Smith and Geoffrey (1968) as "microethnography." During the classroom observations, the behavior of teachers, students, and others who happened into the classroom, was recorded as it happened, in the form of 1ong-hand notes. Insights, inferences and interpretive comments were also recorded during these observations. Informal conversations with teachers, students, teacher aides, and administrators were recorded after they occurred. Classroom observations specifically centered around the various reading groups as they worked together, student-teacher interactions during reading group sessions, student-student interaction relating to the reading group structure of the classroom, and any occurrence that pertained in some fashion to the fact that the classrooms were each divided into different reading ability groups.

Toward the end of October I decided to narrow somewhat the focus of my classroom observations. I had been reading some literature which indicated that reading ability grouping set up a social caste system in

4

For three weeks during January and February the author was denied entrance to the classrooms because of an administrative misunderstanding. 
the classroom (see earlier discussion of Rist, : 1974). Consequently I began to focus on observing the process of reading ability grouping to see if it had such an effect in these desegregated classrooms. However, I continued to record other things that were seemingly nonrelated to reading ability. grouping but which struck my attention as being indicative of the process of desegregation at Garland.

In focusing my observations on reading ability grouping, I began paying more attention to the various reading groups as they met with their teacher for instruction. I also looked for indications in the behavior of teachers and students that reading group membership: was associated with social attractiveness and popularity, (2) developed a sense of social cohesion in only the highest reading groups, and (3) was associated with being thought of as a success or failure in school.

\section{INTERVIEW METHODS}

It is impossible to control for many factors while observing classroom behavior. The teachers and students may be "performing" while the researcher is in the classroom and act differently while he/ she is absent. Because of this type of observer effect, Glaser and Strauss (1967) have maintained that it is often advisable to utilize more than one kind of data. Using more than one kind of data (e.g., using the results of a sociometric questionnaire as well as classroom observations) helps a researcher guard against making erroneous conclusions due to lack of controls.

The students in all three classrooms were administered a sociometric questionnaire by the author in November of 1973 and again in 
May of 1974. The same questionnaire was administered on both occasions (see appendix B). In order to obtain a quantitative measure of social attractiveness and popularity in these classrooms students were asked individually to name three students they would like to sit by if they had a choice and two students they would especially not want to sit next to if they had their choice. In order to get a measure of which students were perceived as successful and which were seen as being failures, each student was asked to name two students he/she thought were doing well in class and two students he/she thought were doing poorly in class. For each classroom, a list was provided by the teacher indicating the breakdown of students into different reading group levels. The sex and race of each student were also recorded.

The administration of the questionnaire began with one student being selected to come to the back of the room and take a chair next to the author (the back of the student faced the rest of the class). The questions were then asked oraliy by the author. If a student did not respond to one of the questions, an answer was not forced. Instead, the next question was asked. Neither the rest of the class nor the teacher could hear the responses of the student during questioning. If. the teacher or another student approached the author while questioning a respondent, the questioning was stopped and resumed only when the intruder moved out of hearing range. This was done in an attempt to provide an uninhibiting atmosphere for the respondent. After the first student had finished answering the questions, another student was selected to come to the back of the room for questioning. This process continued until every student in the classroom had completed the interview. 


\section{QUANTITATIVE METHODS}

After each administration (fall and spring) of the sociometric questionnaire a frequency chart was compiled based on the results. Students were grouped by reading group level, and the frequency of being selected, rejected, perceived as doing we11, and perceived as doing poorly was recorded for each student.

In order to convert the frequency data into a form that would allow measuring the strength of association between reading group membership and social attractiveness; and between reading group membership and peerperceived success or failure, the following procedure was employed to obtain individual scores for each student:- (1) Reading group scores were assigned to every student by ranking the various reading groups in each classroom in a fashion that would provide for comparisons between classrooms with different numbers of reading groups. For example, in one class there were four reading groups and in another there were only three reading groups. Consequently, the highest reading group in each classroom was assigned the number 4 and the lowest reading groups the number 1 . The second and third highest reading groups in the first classroom were then assigned the values 3 and 2 respectively while the second highest reading group in the second classroom was assigned the value of 2.5 (see appendix A). This assignment procedure maximized comparability while maintaining equal distance between reading group scores in each classroom. (2) A social attractiveness score was computed for every student by subtracting the seatmate rejections he/she received from the seatmate selections received. Both seatmate selections and 
rejections were weighted based on their ranking. Three points were given for being the first seatmate selection of another student, two points for being a second choice and one point was awarded for being the third seatmate selection of another student. Likewise, being the first seatmate rejection of another student subtracted two points and being the second seatmate rejection subtracted one point. (3) A score for peer-perceived success was computed for each student by subtracting the number of "doing poorly" classifications he/she received from the number of "doing well" classifications received. (4) A constant of 25 was then added to each social attractiveness and peer perceived success score in order to eliminate negative values and facilitate the ${ }^{-}$ computation of correlation coefficients (see Appendix A).

Pearson's product moment correlation coefficient (Blalock, 1972: 376) was employed to measure association between reading group placement and the sociometric scores. Only the scores of those students who remained in the same reading group throughout the year were used in computing correlation coefficients. ${ }^{5}$ Correlations were obtained on the following relationships: (1) the overall (combining data from all three classrooms) relationship between reading group membership and social attractiveness in the fall and spring, (2) the relationship between reading group

5

In all three classrooms only seven students changed reading groups during the year. There was no consistency in the effect the change in reading group membership had on social attractiveness or peer-perceived success (see the tables in Chapter VII). 
membership and social attractiveness in each classroom for both the fall and spring, (3) the overa 11 relationship between reading group membership and peer-perceived success in the fall and spring, and (4) the relationship between reading group membership and peer-perceived success in each classroom for both the fall and spring. 
READING GROUP. MEMBERSHIP AND SOCIAL ATTRACTIVENESS

\section{THE STRUCTURE AND COMPOSITION OF' READING GROUPS}

Third Grade Number One

There were three reading groups in this classroom, In the fall there were 15 students ( 7 males and 8 females) in the highest reading group, 6 students ( 5 males and 1 female) in the second highest reading group, and 5 students ( 4 males and 1 female) in the lowest reading group. The onty black student in the class, Joseph, ${ }^{1}$ was in the lowest reading group,

By the spring, two students had left the school and a new student had been added to the class. Also; one student had been moved from the second highest reading group to the highest group and two students had moved from the: lowest reading group to the second highest group. These changes left the highest reading group with 15 students ( 7 males and 8 females); the second highest reading group with 7 students ( 5 males and 2 females), and the lowest reading group with 3 students ( 2 males and 1 female). Joseph remained in the lowest reading group all year. The fact that only three students changed reading groups during the course of the year indicated that the ability group structure was essentially fixed and permanent.

$1_{\text {A11 }}$ of the names used in this study are pseudonyms. 
Third Grade Number. Two

There were three reading groups in this classroom. In the fall 11 students (2 males and 9 females) were in the highest reading group, 9 students ( 6 males and 3 females) in the second highest reading group; and 5 students (a11 males) in the lowest reading group. The two black students in this classroom, Leroy and Johnathan, were in the lowest reading group.

During the course of the school year there were no changes in reading group membership in this classroom. All of the students remained in the groups in which they started the year. One new male student arrived in January and was assigned to the second highest reading group, bringing the total in that group to 10 (7 males and 3 females). The fact that no students changed reading groups indicates that the reading ability group structure was a fixed reality in this classroom.

\section{Fourth Gràde}

Unlike the two third grade classrooms, there were four reading groups in this classroom. In the fall there were 6 students $(2$ males and 4 females) in the highest reading group, 9 students $(7$ males and 2 females) in the second highest reading group, 8 students (5 males and 3 females) in the third highest reading group, and 5 students ( 3 males and 2 females) in the lowest reading group. The three black students in this classroom, Jameson, Joey, and Sally, were all in the lowest reading group. 
During the school year four students changed reading groups in this classroom. One of the black students, Joey; left the school in November, and in January, 3 males and 1 female in the second highest reading group were moved down to the third highest reading group. These changes left 6 students" (2 males and 4 females $)$ in the highest reading group, 5 students ( 4 males and 1 female) in the second highest reading group, 12 students ( 8 males and 4 females) in the third highest reading group, and 4 students ( 2 males and 2 females) in the lowest reading group.

\section{READING GROUP ASSIGNMENT PROCEDURES}

A11 three teachers were asked by the author how they assigned students to different reading ability groups. All of them said that they based their decisions on more than one indicator. Mrs. Douglas said that she looked at the student's prior reading record and then listened to him or her read before she made up her mind. Mrs. Young said that she used vocabulary and reading comprehension test results in deciding which reading group a student should be assigned to. Mrs. Frank said that she determined what reading group a student should be assigned to mainly on the basis of classroom performance during the first week of school. She said that she listened to students read out loud and observed their work habits during the first week of school and then assigned them to reading groups on the basis of these observations.

The one common criterion used by all three teachers in assigning students to reading groups was the student!'s ability to read out loud. Mrs. Douglas and Mrs. Young mentioned that they used the student's 
previous record to a certain extent. Mrs. Frank however, maintained that she based her judgment solely on initial performance in class: As far as the black students were concerned, all three teachers had to assign them to reading groups solely on the basis of listening to them read out loud. A conversation with the teachers in the fall revealed that as late as 0ctober 23 , they had not yet received a previous school record for any of the black students in their respective classrooms:

I then asked all three teachers about the previous school records of the black students in their classrooms. All three teachers said that they had not yet received a record or file on the black students in their classrooms. They all said that they were frustrated because without a previous record it was difficult to diagnose why some of the black students had difficulty with the school work.

\section{THE ROUTINE OF READING ABILITY GROUPING}

\section{Third Grade Number One}

In this classroom the teacher, Mrs. Douglas, had set up a partition in the corner of the room where she met with the different reading groups. Although it was difficult for the rest of the class to watch a particular reading group while they were meeting with the teacher, it was easy to hear them:

(March 25, 11:05 a.m.)

I walk into the room and look for Joseph but can't see him. Then I notice that Mrs. Douglas is meeting with the lowest reading group over in the corner of the room. Mrs. Douglas has a big partition that she uses to separate the reading group she is working with from the rest of the class. So I can't see Joseph but I can hear his voice.

Mrs. Douglas generally maintained a consistent routine in working with the various reading groups. She instructed the highest reading 
group first and the lowest reading group last. I observed her working with the highest reading group between 9:30 and 10:00 a.m.,$^{2}$ the second highest reading group between 10:00 and 10:30 a.m., and the lowest reading group between 10:45 and 11:15 a.m. By maintaining this order of instructing the reading.groups, Mrs...Douglas suggested to the class that the highest reading group was. preferred by her. The fact that the teacher prefers a certain group of students can be influential in determining the social preferences of the students. The students might socially prefer students from the highest reading group because the teacher apparently did.

Third Grade Number Two

In this classroom the teacher, Mrs. Young, maintained a generally consistent routine in working with the different reading groups. Between 9:50 and 10:00 a.m. ${ }^{3}$ she would call the highest reading group to assemble in the corner of the room. Unlike Mrs. Douglas, Mrs.. Young did not have a partition that blocked off the reading group she was working with from the rest of the class. Sometime between 10:15 and 10:45 a.m. Mrs. Young usually worked with the second highest reading group, and she normally instructed the lowest reading group between 10:50 and 11:10 a.m. As mentioned earlier in regard to third grade number one,

\section{2}

Only on one occasion did I observe the teacher working with the highest reading group after 10:00 a.m.

3

On only one occasion did I observe Mrs. Young instructing the highest reading group after she had met with the lowest reading group. 
by usually meeting with the highest reading group first the teacher can communicate to the rest of the class that students in the lower reading groups are not as socially desirable as students in the highest reading group.

\section{Fourth Grade}

The routine of reading abifity group instruction was less consistent in the fourth grade classroom than it was in the two third grade classes. For example, the teacher, Mrs. Frank, would sometimes work with the second and third highest reading groups simultaneously, moving from one table to the other:

(Apri1 24, 10:30 a.m.)

I walk into the room and notice that Mrs. Frank is working with the second and third highest reading groups at the same time. She has them seated at different tables. The second highest reading groups is reading out loud in unison and the third highest reading group is working on their workbooks.

Mrs. Frank moves from one table to the next checking on their progress.

Also, the highest reading group would at times leave the room and go to another classroom for instruction. However, in spite of these irregularities, I observed that the lowest reading group was usualiy the last to receive the teacher's attention (generally between 10:40 and 11:10 a.m.). A7though the routine of reading group instruction was not as distinctive in this class as it was in the two third grade classes, by consistently working with the lowest group last Mrs. Frank implied that students in the lowest reading group were not as important as students in the other reading groups. 


\section{DIFFERENTIAL BEHAVIOR ASSOCIATED WITH READING ABILITY GROUPING}

\section{Third Grade Number One}

The instructional sessions varied somewhat between the different reading groups in this classroom. The highest and second highest reading groups experienced a wider range of activities in their reading group sessions than did the lowest reading group. Both the highest and the second highest reading groups put on plays for the whole class as part of their reading group activity:

(January $21,10: 30$ a.m.)

Mrs. Douglas gets up in front of the room and says, "It's time for a break, but first the Monkeys (second highest reading group) are going to present a play for you. You must be patient because they haven't practiced it yet." All the students pull their chairs up and the Monkeys begin their presentation. They announce that they are going to present the story about the Hare and the Tortise.

The lowest reading group never had an opportunity to present a play in front of the whole class.

The highest reading group often seemed to be the focal point of curiosity for the rest of the class. Although the rest of the class could not actually see the highest reading group as they met with the teacher (due to the partition mentioned earlier), they would often turn around in their seats and 7 isten in. The highest reading group often engaged in learning activities that attracted a lot of attention:

$$
\text { (January 21, 9:50 a.m.) }
$$

Mrs. Douglas is over in the corner of the room working with the highest reading group. One half of the group stands and reads out loud to the other half of the reading group who are seated. Now the half of the group that was 
seated stands up and reads out loud in unison to the other half of the group. The rest of the students are supposed to be working on the morning assignments but most of them are turning around to listen in on what the highest reading group is doing.

In contrast to the two highest reading groups, the instructional sessions of the lowest reading group were characterized by a narrow range of learning activities that centered on basic fundamentals. The learning exercises of the lowest reading group seemed non-interesting and this was exacerbated by the time period during which they met. The students generally got increasingly restless during the half hour before lunch $(11: 00-11: 30$ a.m.). This restlessness contributed to the non-interesting atmosphere of the lowest reading group's instructional sessions:

\section{(April 3, 11:00 a.m.)}

Mrs. Douglas calls the lowest reading group together. They meet in one corner of the room that is partitioned off from the rest of the classroom. Because of the partition it is impossible for Mrs. Douglas to see the rest of the class while she is working with a particular reading group. A couple of students leave their desks and walk over to talk with other students. Mrs. Douglas doesn't see this as she is working in the corner of the room with the lowest reading group. (11:05 a.m.) The noise is getting louder as more students are talking instead of doing their work. Duffy is reading out loud while the rest of the reading group 7 istens. Mrs. Douglas now gets out of her chair, walks out away from the partition and tells the rest of the class to quiet down and get back to their seats. Mrs. Douglas goes back to the reading group and tells Joey to read. After Joey reads a couple of paragraphs, Mrs. Douglas says, "You are reading neat Joey." Then she says to the whole group, "You know that students in the other groups often read ahead in their books; it would be good if you people would read ahead during your spare time also." Mrs. Douglas then says, "What kind of a person was John? Was he mean? Bad? Thoughtless?" Duffy says, "He was bad." Joey says, "He was thoughtless." Mrs. Douglas says, "Very good." 
(11:10 a.m.) The rest of the class is getting more restless. Doug and Ron are out of their desks talking with other students. Mrs. Douglas yells out from the corner of the room, "Doug and Ron, I would like to see your work!" Doug and Ron go back to their desks and shuffle through some papers. Mrs. Douglas is now having the lowest reading group work on vowel sounds. Joseph recites the vowel sounds. - Mrs. Douglas then starts saying different words and has the students in the lowest reading group sound out vowels.

(11:16 a.m.) Mrs. Douglas dismisses the lowest reading group and tells the class to get ready for lunch.

By engaging in activities that attract the attention of classmates (e.g., putting on plays), students in the two highest reading groups were able to "show off" their personalities. This kind of social exposure was not available to students in the lowest reading group. Consequently, students in the lowest reading group had less opportunity to appear as socially attractive personalities.

Third Grade Number Two

As in third grade number one, the highest reading group in this classroom engaged in interesting activities during their reading group sessions. They put on a play for the whole class as part of their reading group activity:

(March 4, 10:00 a.m.)

Mrs. Young calls the first (highest) reading group together. The name of their textbook is High Roads. They all sit in a circle and start discussing a play they are going to perform for the whole class. Mrs. Young tells Ronnie that he is going to be the moderator. She explains that this means he is to introduce the play, the different scenes in the play and the actors and actresses. The reading group then discusses the different characters in the play. A couple of the girls talk about the costumes they are going to make. The rest of the class is watching the group as they talk about the play. 
As mentioned before, activities such as plays are vehicles for appearing socially attractive. There are other vehicles of course, such as athletics, but the point here is that certain opportunities are available only to certain students. "I did not" observe the two lower reading groups put on plays for the whole class. This was unlike third grade number one where the second highest reading group as well as the highest group put on a play.

Another difference between the instructional sessions of the different reading groups had to do with Mrs. Young's behavior. While working with the two highest reading groups she seemed to concentrate more than when she worked with the lowest reading group. While working with the two highest reading groups Mrs. Young would not allow other students to interrupt:

(January $37,10: 35$ a.m.)

Travis (a member of the lowest reading group) gets up and approaches Mrs. Young who is working with the second highest reading group. Apparentiy he has a question about the morning's assignment. Mrs. Young says, "Not this minute Travis." Travis walks back to his seat.

However, when she was working with the lowest reading group she would often allow other students to interrupt the session:

(March 12, 10:45 a.m.)

Mrs. Young calls for the lowest reading group to assemble in the corner of the room. The group sits around in a circle with Mrs. Young. Mrs. Young says, "What was the story about?" Warren says, "It was about a horse that needed shoes." Mrs. Young says, "That's right the name of the story is How Herbie Gets a Shoe." She then says, "Why did Herbie need a shoe?" Nobody in the group is able to answer this question so Mrs. Young tells them to finish reading the story. As they read, Mrs. Young is answering questions from students who walk over to where she is meeting with the lowest reading group. 
I've counted four different students who have approached her with questions about their assignments while she is sitting with the lowest reading group.

The group finishes reading the story and Mrs. Young starts asking questions again. Johnathan raises his hand and before he can answer Mrs. Young says, "Johnathan take whatever you have 'in your mouth out." Johnathan gets up, goes back to the trash can, and spits his gum out. When he returns to the group Mrs.... Young ...asks the question again. Johnathan gives a wrong answer and the teacher tells him to read over part of the story again. Mrs. Young then tells the whole reading group to go back to their desks and read the story again.

$$
\text { (Apri1 22, 10:55, a.m.) }
$$

Mrs. Young calls the lowest reading group together for instruction. She has them take out their workbooks and go over the exercise that they have just completed. She asks Johnathan, "Did the children always have time to play with Fredie?" Johnathan says, "The answer is true." Mrs. Young says, "No, the answer is false, the children had to go to school and so they didn't always have a chance to play with Fredie." Elaine, a girl from the highest reading group interrupts the session by asking Mrs. Young a question about the math assignment. Mrs. Young spends two minutes answer her question.

By entertaining questions from other students while she was working with the lowest reading group, Mrs. Young gave the impression that students in the lowest reading group were not as important as students in the other reading groups. By exhibiting a preference to interact with students in the higher reading groups the teacher implied that students in the lowest reading group were not as socially attractive as students in the higher reading groups.

Fourth Grade

In this room there did not appear to be any distinctive difference in the reading group sessions of the second and third highest reading 
groups. The highest reading group was given special treatment in that they were often allowed to work by themselves without the teacher's presence. On these occasions Mrs. Frank would assign them (the highest reading group) a certain task (e.g., discuss and answer questions about a certain story), and then let them go off by themselves (they would leave the room) to accomplish the task on their own. As in the two third grade classes, the sessions of the lowest reading group tended to stress fundamentals. Consequentiy, the instructional sessions of the lowest reading group lacked the variety of learning activity present in the sessions of the other reading groups.

In addition to the-differences-in behavior between reading group sessions, reading group membership influenced social behavior in other ways as well. In this classroom, as well as in the two third grade classrooms, students periodically elected class officers. Most of the elected positions were single person offices such as ball monitor, book monitor, chalk board monitor, etc. On the other hand, some of the elected positions were joint offices such as host and hostess, and girls' and boys' president. In all three classrooms most of the students, at some time during the year, were elected to an office. However, in the fourth grade classroom the joint offices tended to be occupied by students from the same reading group:

(Apri1 17, 11:00,a.m.)

Mrs. Frank gets up and addresses the whole class, "When we have a guest, we need to have someone to greet them. Does anybody want to be our official greeter for the class?" Jameson jumps up and down raising his hand, so do a number of other students. Mrs. Frank then says, "I think the president of the boys and the president of the girls should be our host and hostess for greeting parents who might 
visit our room (it's parents visitation week). $\therefore$ That would be Jeff and Elsa." ..Jeff and Elsa are both members of the first reading group. Another student raises his hand and says, "Since we elect a host and hostess for lunch periods each week, why not have them be the greeters?" Mrs. Frank says, "Maybe we should vote on it." The students vote to have the host and hostess for the week be the official greeters. The host and hostess for this week are Allen and Barbara. Both of them are in the third highest reading group.

Thus, reading ability grouping seemed to predispose the students to socially discriminate on the basis of reading group membership, and to accept the idea that students from the same group "belong together" in situations not intrinsically related to academic performance. This kind of social differentiation based on reading group membership could lead students from higher reading groups to feel uncomfortable associating with students from lower reading groups.

SOCIAL COHESION AMONG READING GROUPS

Third Grade Numbër One

I did not observe a strong sense of group solidarity among the three reading groups in this classroom. The highest reading group had the most students. In fact, over half of the class (15 out of 26 students) was in the highest reading group. The large size of the highest reading group seemed to work against the establishment of a clique.

Both the second highest and lowest reading group changed composition during the course of the year. The second highest reading group lost two students (one dropped out of school and the other graduated to the highest reading group) and gained three students (two students from 
the lowest reading group and one new student) during the year. The lowest reading group also lost two students (two members graduated to the second highest reading group) during the course of the school year. At the end of the year there were oniy three students in the lowest reading group. The shift in membership in both of these reading groups worked against the establishment of group solidarity.

\section{Third Grade Number Two}

As in third grade number one, the highest reading group in this classroom contained more students than either of the other two reading groups. However, unlike the other third grade classroom, over half of the students in this classroom were not members of the highest reading group (only 11 out of 25 students in the highest reading group as opposed to 15 out of 26 students in third grade number one) and there were no changes in reading group membership during the year. These two factors (i.e., smaller size of higher reading group, no changes in reading group membership) created a situation that was conducive to group cohesiveness among reading groups.

Although I did not observe any strong examples of reading group cohesiveness within this classroom, reading group membership was used as a reference point in social interaction. In the following instance a girl from the highest reading group in this classroom used her reading group status as a means to domineer a girl from the fourth grade class. The girl from the fourth grade class was a member of the lowest reading group in her classroom: 
(May 23, 2:10. p.m.)

I walk out onto the playground and notice the two third grade classrooms have just been let out for their afternoon recess. The fourth grade was already on the playground. I begin watching Gloria. She walks up to a group of third graders who are playing two-square and she tries to cut in front of the line. Diane, a girl from the highest reading group in Mrs. Young's class, is standing there. Gloria says, "Let me in front." Diane replies, "No, I won't let you in front." Gloria then says, "Well I'm a fourth grader and you're just a third grader." Diane replies, "Well you're stupid, stupid, you're not even in a higher reading group than I am. I' $m$ in a higher reading group than you. You're only on Story Caravan and I'm in American Adventures already." Four other third graders are standing around listening to the exchange. Gloria turns without saying a word and walks to the end of the line. As she walks Diane shouts, "You're just a dumb girl, go to the end of the line."

It should also. be noted that the lowest reading group in this classroom was composed of all males. Since third grade children are of an age at which there tends to occur a strong boy-girl rivalry, the fact that the lowest reading group was all male could contribute to a sense of group solidarity. The potential for group cohesiveness in the lowest reading group was enhanced by the fact that the best athlete in the class, Butch, was a member of the lowest reading group:

(May 13, 10:10 a.m.)

Mrs. Douglas' class is up first. Butch is pitching for Mrs. Young's class. Mrs: Young walked over to me and saýs, "I just love this, I just love to watch the kids play against each other like this." She then points at Butch and says, ' "He's going to be a great athlete someday."

Having the best athlete in the class gave the lowest reading group a sense of pride and encouraged group identity. 
Fourth Grade

The highest reading group in this class was a clique. The membership was sma11; only six.students. The group stayed intact al1 year; there were no new members and nobody left the group. As mentioned earlier, the teacher allowed these students to leave the room as a group and meet "on their own." A1l of these factors contributed to a sense of exclusiveness and group solidarity within this reading group.

The second and third highest reading groups were not as cohesive as the highest reading group. Four members of the second highest reading group were demoted to the third highest reading group during the year. This change in group membership worked against the establishment of a strong group identity. Also, as mentioned earlier, the teacher treated the second and third highest reading groups the same. She often worked with these two groups simultaneousiy.

The lowest reading group seemed to be fragmented. One of the black students dropped out of school in the fall leaving the group with only four members. Of the remaining four members, only the two girls (Sally and Gloria) expressed any social attraction to each other. I often observed them playing together on the playground. Jameson, the remaining black male, didn't associate with any other student on a regular basis, and Henry disowned the other members of the lowest reading group by acting as though he really didn't belong in the group. 


\section{QUANTITATIVE DATA}

\section{Reading Group Membership and Social Attractiveness}

The overall correlations between reading group membership and social attractiveness among the three classrooms were not very strong. Taking all three classrooms wogether, the correlation between reading group membership and social attractiveness was stronger in the fall $\left(r=.3772, r^{2}=.14\right)$ than in the spring $\left(r=.2268, r^{2}=.05\right)$. This suggests that the relationship between reading group membership and social attractiveness established itself early in the year (the first sociometric test was administered in November), then weakened as the year progressed. These data indicate that the routines and differential behavior associated with reading ability grouping in these classrooms did not establish a strong relationship between reading group membership and social attractiveness, as reading group membership accounted for only five percent of the variation in social attractiveness in the spring.

The correlations within the different classrooms also indicate that, in all three classrooms, the relationship between reading group membership and social attractiveness weakened between the fall and spring (see Table IIIL. The association between reading group membership and social attractiveness was strongest in the fourth grade classroom. In the fall, reading group membership accounted for 22 percent of the variance in social attractiveness in the fourth.grade class. 


\section{TABLE III}

\section{CORRELATIONS BETWEEN READING GROUP MEMBERSHIP \\ AND SOCIAL ATTRACTIVENESS}

Fal1

A11 Three Classrooms Combined

$$
r=.3772, r^{2}=.14
$$$$
r=.2268, r^{2}=.05
$$

Third Grade Number One

$r=.2678, r^{2}=.07$ $r=.2543, r^{2}=.06$

Third Grade Number Two

$r=.3856, r^{2}=.15$

$r=.0981, r^{2}=.01$

Fourth Grade
Spring

$$
05
$$


Other Variables Associated With Social Attractiveness in the Classroom

Variables other than reading group membership have been reported as being related to social attractiveness at this age level (i.e., third and fourth grades). A number of studies have reported withingender social preferences (Raths,"1946; fifth and sixth grades; Biehler, 1954, kindergarten; Tep 1in, 7972, third grade). A7so, as mentioned earlier, social class has been found to have an effect on a student's social attractiveness--the higher the social class, the more socially attractive the student (Neugarten, 1947; Rist, 1974). In light of these studies, an effort was made to ascertain the effect of these other factors on social attractiveness in the classrooms under study.

Gender. With regard to seatmate selections, the gender bias was very extreme in the three classrooms under study. In the fall and spring combined, there was only one cross-gender seatmate selection (see Table IV). This marked gender bias need not have distorted the relationship between reading group membership and social attraction.' Even if males chose only males and females chose only females, if there was a relationship between reading group membership and social attractiveness, males could have chosen males from the highest reading group and females could have chosen females from the highest reading group. This did not happen consistently enough to produce strong correlation coefficients. 
TABLE IV

\section{THE EFFECT OF GENDER ON \\ SEATMATE SELECTIONS \\ (first selections)}

Third Grade Number One

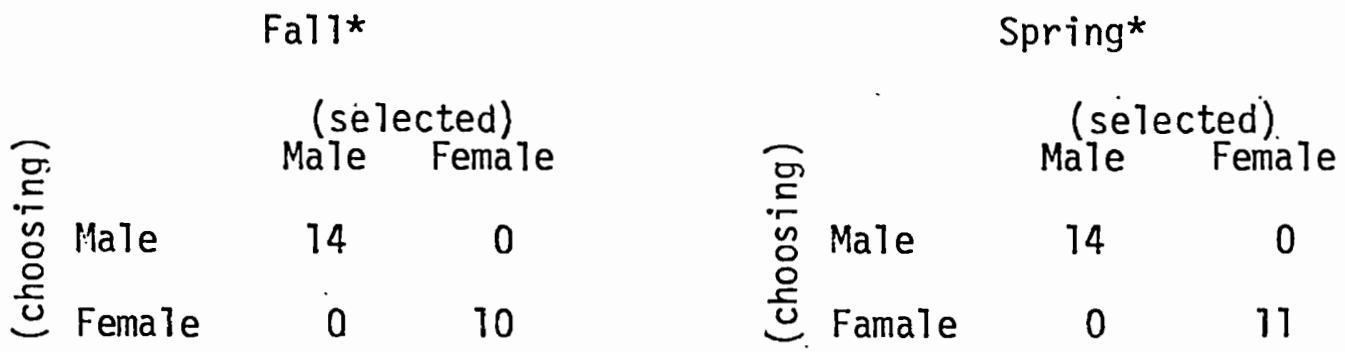

Third Grade Number-Two

\begin{tabular}{|c|c|c|c|c|c|c|}
\hline & $\mathrm{Fall}$ * & & & & pring' & \\
\hline & (se & cted) & & & (se & ted) \\
\hline E. & Male & Female & E. & & Male & Fema Te \\
\hline$\stackrel{-}{y}$ Male & 12 & 0 & $\tilde{0}$ & Male & 14 & 0 \\
\hline Female & 1 & 10 & ड & Female & 0 & 12 \\
\hline
\end{tabular}

Fourth Grade

\begin{tabular}{|c|c|c|c|c|c|c|}
\hline \multicolumn{3}{|c|}{ Fall* } & & \multicolumn{3}{|c|}{ Spring* } \\
\hline & \multicolumn{2}{|c|}{ (selected) } & \multirow{4}{*}{ 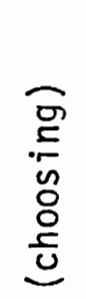 } & & \multicolumn{2}{|c|}{ (selected) } \\
\hline & Male & Female & & & Male & Female \\
\hline Male & 15 & 0 & & Male & 16 & 0 \\
\hline Female & 0 & 11 & & Female & 0 & 11 \\
\hline
\end{tabular}


Gender bias was less marked with regard to seatmate rejections than it was with seatmate selections. However, there was still a clear tendency to reject members of the opposite sex in the two third grade classrooms (see Table $V$ ). This tendency was less distinct in the fourth grade classroom, but as in the third grade rooms, gender bias with regard to seatmate rejections increased in strength in the fourth grade class between the fall and spring (see Table V).

Gender bias in seatmate rejections had a stronger effect in reducing correlations between reading group membership and social attractiveness than did the gender bias in seatmate selections. The tendency to reject members of the highest reading group because of their sex influenced the relationship between reading group membership and social attractiveness. As the gender bias in seatmate rejections increased from fall to spring (see Table $V$ ), the correlations between reading group membership and social attractiveness weakened.

Social Class. The three classrooms under consideration were rather homogeneous with regard to social class. All of the white students had parents with middle to upper-middle class occupations (e.g., executives, professionals, and salesmen). The only students with a lower-class background (e.g., welfare, blue-collar labor) were the black students. The largest number of blacks in any of the three classrooms was three. Consequently, these classrooms were rather uniform in their social class composition. This homogeneity of social class ruled out the emergence of a strong effect of social class on social attractiveness. In 


\section{TABLE V}

THE EFFECT OF GENDER ON

SEATMATE REJECTIONS

Third Grade Number One

Fal1

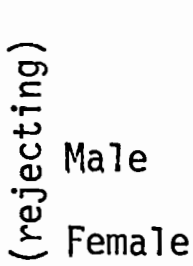

(rejected)

2

3 Male Female
9

5

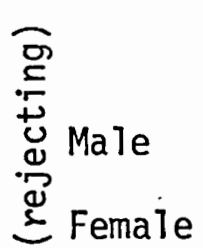

Spring*

Third Grade Number Two
Spring*

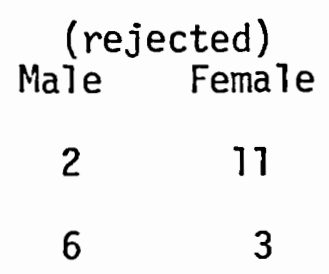

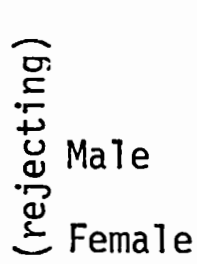

$\mathrm{Fall}$

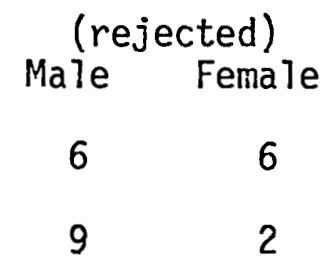

Fourth Grade

\section{Fall}

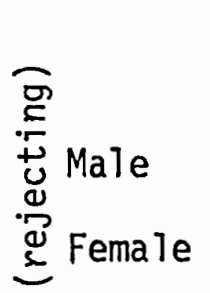

$\star P<.05$

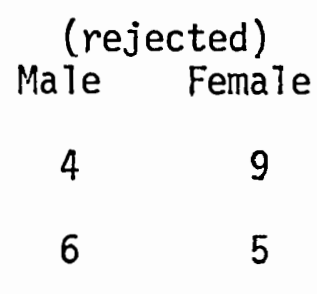

(rejected)

9

5

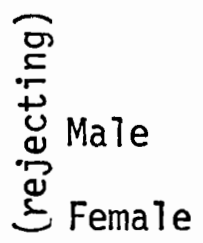

Spring

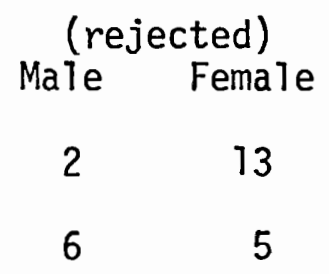


contrast to Rist's (1974) study, the association between reading group membership and social attractiveness in these classrooms cannot be attributed to differential treatment based on social class.

Social class and race were inseparable in these classrooms. The black students were also the lower class students. A discussion of reading group membership and the social attractiveness of the black students in these three classrooms will be found in Chapter VII.

\section{SOCIAL COHESIVENESS WITHIN READING GROUPS}

In order to come up with a quantitative measure of reading group cohesiveness, direct probabilities were calculated on the number of within group, as opposed to without group, first seatmate selections for each reading group. Based on this measure the degree of social cohesiveness within reading groups varied considerably between classrooms. In third grade number one, contrary to the findings of Rist (1974) and McGinley and McGinley (1970), the highest reading group did not exhibit a strong sense of group cohesion (see Table VI). In both the fall and spring, members of the highest reading group in this class chose students from the lower reading groups as their first seatmate selections. In line with the studies of Rist and McGinley and McGinley, the highest reading group in third grade number two demonstrated a strong sense of group cohesion by overwhelmingly prefering students from their own group as first seatmate selections. However, in this same classroom, the lowest reading group also demonstrated a strong sense of group cohesion (see Table VI). The strong group cohesion expressed by the lowest 
TABLE VI

READING GROUP COHESIVENESS: DIRECT PROBABILITIES

OF FIRST SEATMATE SELECTIONS

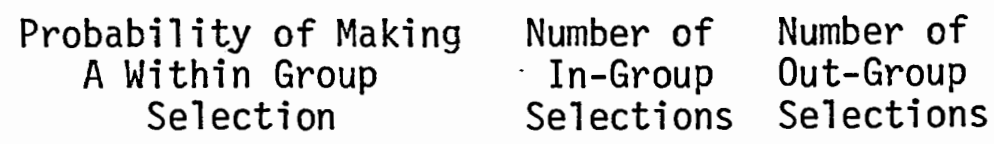

Third Grade Number One

Fall

Highest Reading Group

$(.58)$

8

6 NS*

Second Highest Reading Group

Lowest Reading Group

2
0

3 NS

$0 \quad 5$ NS

\section{Spring}

Highest Reading Group

Second Highest Reading

10

5 NS

Group

Lowest Reading Group

6 NS

3 NS

Third Grade Number Two

Fall

Highest Reading Group

Second Highest Reading

$0 p=.0001$

Group

Lowest Reading Group

$\begin{array}{ll}2 & 6 \mathrm{NS} \\ 4 & 1 \mathrm{p}=.006\end{array}$

Spring

Highest Reading Group

9

$2 p=.008$

Second Highest Reading

Lowest Reading Group

$\begin{array}{ll}3 & 7 \mathrm{NS} \\ 4 & 1 \mathrm{p}=.005\end{array}$

*Probability not statistically significant, $p>05$. 
reading group runs contrary to the findings of McGinley and McGinTey (1970) which indicate that the students in the lowest reading groups prefer to associate with students from higher reading groups.

Of all the classrooms, only the fourth grade class revealed the kind of social cohesion pattern reported in the studies of Rist (1974) and McGinley and McGinley (1970). In this room, students in the highest reading group preferred to associate with students from their own reading group while the rest of the reading groups exhibited little within-group preference (see Table VI).. This pattern of social cohesion among the reading groups in the fourth grade class is consistent with the finding that the correlation between reading group membership and social attractiveness was the strongest in this classroom.

\section{SUMMARY}

The data presented in this chapter indicate that the routine (e.g., whether or not a partition separates the reading group from the rest of the class, which groups are instructed first, etc.) and differential learning activities (e.g., the higher reading groups experiencing a greater variety of learning activities) associated with the practice of reading ability grouping are not as influential as the structure and composition of reading groups in the creation of a relationship between reading group membership and social attractiveness in the classroom. The (fourth-grade) classroom in which the relationship between reading group membership and social attractiveness was the strongest differed from the other classrooms in that it had more 


\section{TABLE VI}

\section{READING GROUP COHESIVENESS: DIRECT PROBABILITIES \\ OF FIRST SEATMATE SELECTIONS \\ (continued)}
Probability of Making Number of Number of A Within Group In-Group Out-Group Selection Selections Selections

Fourth Grade

\section{Fal1}

Highest Reading. Group

4

$2 p=.018$

Second Highest Reading

3

6 NS*

Third Highest Reading

3

4 NS

Lowest Reading Group

\section{Spring}

Highest Reading Group

Second Highest Reading Group

Third Highest Reading Group

Lowest Reading Group

*Probability not statistically significant, $p>05$. 
reading groups (four as opposed to three in the other two classrooms) and fewer students in the highest reading group (six as opposed to eleven and fifteen respectively in the other two classrooms). The fourth grade classroom was also the only room where students seemed to socially discriminate based on reading group membership. They did this by electing only students from the same reading group to hold joint girl-boy offices such as host and hostess.

Unlike Rist's (1974) study, there was not a clear case of social class cleavage between reading groups. ${ }^{4}$ Social class was not a salient factor in the composition of reading groups. The results of this study suggest that when the different reading groups do not represent different levels of social class backgrounds, the relationship between reading group membership and social attractiveness is somewhat tenuous.

In the absence of a social class cleavage between reading groups, variables such as gender bias play a more important role in determining the relationship between reading group membership and social attractiveness. A good example of this was in third grade number two where the a11 male lowest reading group developed a strong sense of group cohesiveness and thereby thwarted the establishement of a strong relationship between reading group membership and social attractiveness.

In general, the preceding data indicate that reading group membership may be a contributing factor to social attractiveness in the classroom. However, its contribution to a student's social attractiveness

4.

McGinley and McGinley (1970) did not report on the variable of social class. Therefore it is impossible to know what effect social class had on their results. 
was rather small in the three classrooms under study. In a number of cases other variables such as gender, athletic ability, and personality appear to have overridden reading group membership in determining a student's social attractiveness. Also, the data on reading group choesiveness indicated that, contrary to Rist (1974) and McGinley and McGintey (1970), reading group cohesiveness (i.e., within reading group seatmate selections) is a function of size and gender composition as well as reading group level. 


\section{CHAPTER VI}

\section{READING GROUP MEMBERSHIP AND \\ PEER PERCEIVED SUCCESS}

\section{THE ROUTINE AND DIFFERENTIAL LEARNING ACTIVITIES ASSOCIATED WITH READING ABILITY GROUPING}

The routine and differential learning activities (depicted in the previous chapter) associated with reading ability grouping seemed to contribute to an image of success for students in the highest reading groups and an image of failure for students in the lowest reading groups. By consistently meeting with the highest reading groups first and the lowest reading groups last, the teachers suggested that the students in the highest reading groups had a potential for success while the students in the lowest reading groups lacked such potential. Also, as mentioned in the previous chapter, the greater variety of learning activities engaged in by students in the highest reading groups gave them a greater opportunity to demonstrate their competence and appear as successfur students, compared to students in the lowest reading groups who were limited to a narrow range of learning activities.

The differential behavior associated with reading ability grouping (described in the previous chapter) contributed to an image of success among students in the highest reading groups and an image of failure among students in the lowest reading group. In third grade number two, 
the teacher would entertain questions from other students while working with the lowest reading group but would refuse to answer questions from other students while working with the higher reading groups. This differential behavior on the part of the teacher gave the impression that students in the higher reading groups had potential for achievement while those in the lowest reading group did not have such potential. Also, the independence allowed members of the highest reading group in the fourth grade classroom depicted them as more mature and successful than students from the lower reading groups.

\section{QUANTITATIVE DATA}

Grouping the data from all three classrooms together, the correlation between reading group membership and peer-perceived success was the same in the spring and in the fall. In both the fall and spring, reading group membership accounted for about 29 percent of the variation in peer-perceived success scores (see Table VII). Taking all three classes together, the correlation between reading group membership and peer-perceived success was stronger than the overall correlation between reading group membership and social attractiveness.

Although the overall correlation between reading group membership and peer-perceived success was the same in the falt and spring, there were some differences between classrooms. In third grade number one, the correlation between reading group membership and peer-perceived success was stronger in the spring than it had been in the fall (see Table VII). Apparently the routine and differential behavior associated 


\section{TABLE VII}

CORRELATIONS BETWEEN READING GROUP MEMBERSHIP

AND PEER-PERCEIVED SUCCESS

\section{Fall}

Spring

A17 Three Classrooms Together

$$
r=.5344, r^{2}=.29 \quad r=.5395, r^{2}=.29
$$

Third Grade Number One

$$
r=.2597, r^{2}=.07 \quad r=.5097, r^{2}=.26
$$

Third Grade Number Two

$$
r=.6297, r^{2}=.40 \quad r=.5099, r^{2}=.26
$$

Fourth Grade

$$
r=.6694, r^{2}=.45 \quad r=.6633, r^{2}=.44
$$


with reading ability grouping in third grade number one, strengthened the association between reading group membership and image of success over the course of the year.

In contrast to third grade number one, in third grade number two the correlation between reading group membership and peer-perceived success was somewhat weaker in the spring than it had been in the fall (see Table VII):. As mentioned in the previous chapter, third grade number two differed markedly from the other two classrooms in that the lowest reading group was very socially cohesive throughout the year. Their cohesiveness revolved around having the best athlete in the class, Butch, as a member of the group. A comparison of the fall and spring measures of peer-perceived success shows that three of the five students in the lowest reading group received higher peer-perceived success scores in the spring than they had in the fall..$^{1}$ Butch's peer-perceived success score went from 24 in the fall, to 28 in the spring. Having the best athlete in the class as a member of the lowest reading group seems to have overridden the routine and differential behavior associated with reading ability grouping and caused a reduction in the strength of the correlation between reading group membership and peer-perceived success as the school year progressed.

The fourth grade class followed the pattern of the overall correlations (taking all three classrooms together) in that the 
correlation between reading group membership and peer-perceived success was about the same in the spring as it had been in the fall (see Table VII). The relationship between reading group membership and peer-perceived success was stronger in the fourth grade than in the two third grade classrooms. In the fourth grade classroom, reading group membership accounted for about 45 percent of the variation in peerperceived success in both the fall and spring.

\section{SUMMARY}

Reading group membership in the three classrooms under study was more strongiy associated with an image of success or failure than with social attractiveness. The structure, composition, routine, and differential behavior associated with the practice of reading ability grouping in these classrooms contributed more to a student's image of competence than to his/her social appeal. The relationship between reading group membership and peer-perceived success was strongest in a classroom (fourth grade) where the structure and composition of reading ability grouping, as well as differential behavior on the part of the teacher and students, produced a situation where the highest reading group resembled a small social clique.

Although the relationship between reading group membership and peer-perceived success was stronger than the relationship between reading group membership and social attractiveness, it was vulnerable to the weakening effects of. other indicators of success. In third grade number two where the best athlete (another indicator of success) was in 
the lowest reading group, the relationship between reading group membership and peer-perceived success weakened over the course of the school year. 
CHAPTER VII

\section{READING ABILITY GROUPING AND SCHOOL DESEGREGATION: SOCIAL ATTRACTIVENESS AND IMAGE OF SUCCESS AMONG BLACK STUDENTS}

Before considering the effect of reading ability grouping on the social attractiveness and image of success of black students, it should be noted, as mentioned earlier, that Garland represents a particular type of school desegregation. There were very few blacks and they represented a distinctively lower social class than their white peers. Also, the black students were bused from schools that had a markedly lower achievement level than Garland's. These conditions should be kept in mind while considering the data regarding the social attractiveness and image of success among black students.

Third Grade Number One

READING ABILITY GROUPING AND THE SOCIAL ATTRACTIVENESS

OF BLACK STUDENTS

As mentioned earlier, Joseph was a member of the lowest reading group. In light of the weak correlations between reading group membership and social attractiveness in this classroom, the fact that Joseph was a member of the lowest reading group should have had little effect on his social attractiveness. However, a close look is in order here.

In the fall, Joseph was neither selected or rejected as a seatmate. This gave him a lower social attractiveness score than most of the 
other students in the lowest reading group (see Table VIII). In the spring however, one student chose Joseph as his first seatmate selection. It is interesting to note that the only student to select Joseph as a seatmate, Mickey, received the lowest social attractiveness score in the highest reading group (see Table VIII) and was considered an outsider in the class. Toward the end of the year the :teacher mentioned Mickey in a conversation I had with her:

(May 30, 3:30 p.m.)

"Mickey's been an outsider this year. He doesn't seem to have befriended anyone. The kids really exclude him from their activities. I've talked to some of the children about including him more in their activities but they just won't respond. And these kids are usually pretty fair and sensitive to each other, but they just won't go near Mickey. Mickey is very intelligent, but he isn't consistent in getting his work done. Some of the stories he has written have contained abstract notions far ahead of his grade level. He's very tight inside. It seems as though there's a war going on inside of him."

One of the ways in which students show off their personalities is though "Sharing Time." In this classroom "Sharing Time" was usually held right after lunch. It was also during this time (four days a week) that Joseph left the room for remedial reading instruction. Consequently, his access to this vehicle of social recognition was limited.

The most socially attractive student in the class was Charley, who was in the highest reading group and received the highest social attraction score (see Table VIII). Charley not only was in the highest reading group, he was also a good athlete. When the two third grade classrooms played against each other in kick bal1, Mrs. Douglas made Charley the captain of the team and had him do the pitching: 
TABLE VIII

SOCIAL ATTRACTION SCORES BY READING GROUP:

THIRD GRADE NUMBER ONE

Fàll

Spring

Group I (highest reading group)

Group I

*S1 M 26

S2 $\quad M \quad 24$

S2 M 23

S3 $\quad M \quad 19$

S3 M 25

S4 M 25

S4 M 28

S5 $F \quad 24$

S5 $F \quad 25$

S6 $\mathrm{F} \quad 37$

S6 $F \quad 27$

S7 $F \quad 30$

S7 $F \quad 35$

S8 $\quad M \quad 29$

S8 M 29

S9 $F \quad 26$

$\begin{array}{lll}S 9 & F & 32\end{array}$

S $10 \quad F \quad 38$

S10 $F \quad 34$

S11 $F \quad 28$

Sil F 28

S12 F 29

S12 F 30

S13 明 49

S13 M 49

S14 M 28

S14 M 28

S15 $F \quad 25$

S15 $F \quad 23$ Average $=29.47$

S16 M 28

Average $=29.47$

Group II

Group II

S16 M 24

S17 $\quad M \quad 24$

S17 M 25

$\mathrm{S} 18 \cdot \mathrm{F} 14$

S18 $F \quad 27$

S20 M 43

*S19 M 27

S21 M 29

S20 M 40

S22 M 28

S27 M 32 Average $=29.17$

S25 M 26

$* * * S 27 \quad F \quad 38$ Average $=28.89$

Group III

Group III

$\begin{array}{rcr}\text { S22 } & M & 26 \\ \text { S23 } & M & 32 \\ * * S 24 & M & 25 \\ \text { S25 } & M & 27 \\ \text { S26 } & F & 16\end{array}$

$\begin{array}{rrr}\mathrm{S} 23 & \mathrm{M} & 30 \\ * * \mathrm{~S} 24 & \mathrm{M} & 33 \\ \mathrm{~S} 26 & \mathrm{~F} & 16\end{array}$

Average $=23$

S26 F 16 Average $=24.2$

* Student dropped out of school by spring

** Black student (Joseph)

*** New student arriving in January, 1974 
(May 13, 10:26 a.m.)

Douglas' room lines up. They are first up. Sam is pitching for Mrs. Young's room. Douglas' class scores four runs their first time up. Mrs. Douglas tells Charley to do the pitching for her class. The students seem to accept Charley as their team leader.

Although Charley was a good athlete, he wasn't the best athlete in the class. Observations of a number of occasions on which Mrs. Douglas' class competed against third grade number two in kick ball indicated that Joseph was the best athlete in the class:

(May 28, 10:40 a.m.)

Mrs. Douglas' class takes the field. The first four people up for Mrs. Young's class get on base scoring two runs. The next player up for Young's room kicks a fly ball that is caught by Joseph. After catching the ball, Joseph runs to second base and tags out the runner who is caught off base. Mrs. Douglas turns to me and says, "If it weren't for Joseph we'd be in trouble."

(June 3, 10:35 a.m.)

The score is tied at one to one. Mrs. Douglas' team is in the field. Mrs. Young's team loads the bases. The next player up kicks a fly ball that is caught by Joseph. After catching the ball he tags first and then tags second catching two players off base and making a triple play. Joseph jumps up and down and says "I made three in one." A couple of his teammates grab him and show their approval. Mrs. Douglas' room went on to win the game three to one.

Although the fact that Charley was a good athlete seemed to enhance his social attractiveness, the fact that Joseph was the best athlete in the class didn't seem to increase his social attractiveness. Joseph's membership in the lowest reading group can be viewed as a contributing factor in lessening the social attractiveness of his athletic ability. 
Third Grade Number Two

In the fall both Leroy and Johnathan were relatively popular compared to other members of the lowest reading group. In fact, Leroy had a social attractiveness score that was higher than the average score for the second highest reading group (see Table IX). At the first of the year the white students seemed somewhat interested in the novelty of having black students in the classroom. As in the other third grade classroom, "Sharing Time" was a vehicle for students to gain the recognition of their peers. On one afternoon early in the year I observed Leroy telling the rest of the class about some of his experiences:

(0ctober $30,12: 25$ p.m.)

Leroy, one of the black students, is the first to get up in front of the room. He talks about playing with a friend of his named Buddy who is 13 years old. He is talking in a low voice and the teacher tells him to speak up. His voice is louder now and he talks about shooting birds with a b-b gun. He says that he and his friend Buddy also shoot at each other. This remark draws some ohs and ahs from the class. Leroy goes on to say that he and Buddy jump from roof top to roof top while they are shooting at each other. Leroy really seems to be enjoying himself while he is telling of his experiences. The class is really attentive.

After Leroy has talked for about seven minutes, Mrs. Young says, "That's enough, let's have someone else talk." As soon as Leroy sits down, Mrs. Young comes over to me and says, "Did you get all that down? I know most of it wasn't true, but it was interesting so I kind of wanted him to tell it anyway."

After the first of the year however, I never observed Leroy or Johnathan participate in "Sharing Time." Part of: the reason for this was that Leroy and Johnathan were often taken out of the room for special reading sessions during this period. "Sharing Time" took place after the students returned from lunch (12:20-12:50 p.m.). 
TABLE IX

SOCIAL ATTRACTION SCORES BY READING GROUP:

THIRD GRADE NUMBER TWO

Fal1

Group I (highest reading group)

S1 $F \quad 32$

S2 $\quad F \quad 24$

S3 $\quad F \quad 31$

S4 F 30

S5 $\quad F \quad 34$

S6 M 22

S7 $F \quad 32$

$\begin{array}{lll}S 8 & F & 29\end{array}$

S9 $F \quad 32$

S10 $\quad$ M 36

Sil F 29

Group II

S12 M 23

S13 M 29

S14 M 25

S15 $\cdot F \quad 28$

S16 $F \quad 22$

S17 M 25

S18 M 38

S19 F 23

S20 M 32

\author{
Average $=30.09$ \\ Average $=27.22$

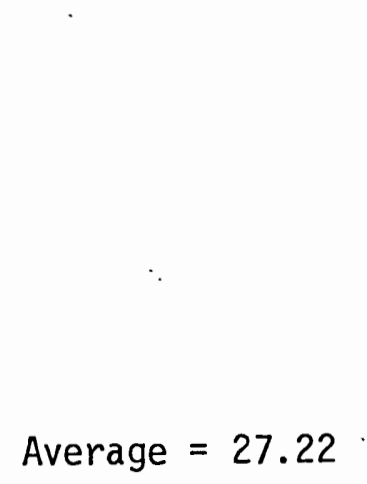

Group III
- Group II

$\begin{array}{lll}S 12 & M & 27\end{array}$

S13 M 37

S14 M 23

S15 F 30

S16 F 29

S17 M 24

S18 M 28

S19 F 27

S20 M 29

*S26 M 28 Average $=28.2$

Group III

$\begin{array}{rrr}* * S 21 & M & 27 \\ S 22 & M & 29 \\ S 23 & M & 10 \\ \text { S24 } & M & 42 \\ * * S 25 & M & 26\end{array}$

Average $=17$

White Average $=21.67$

B lack Average $=3.28$
Average $=26.8$

White Average $=27$

Black Average $=26.5$

* New student

** Black student 
(January 24, 12:45 p.m.)

Mrs. Young then came over to where I was sitting. I asked her where Johnathan and Leroy were. She said that they were in their remedial reading session. I then asked her how often they were taken out of class for these special reading sessions. She said that they were taken out of class four days a week (Monday, Wednesday, Thursday, and Friday), between 12:30 and 1:00 p:m. for special reading instruction.

(March 26, 12:30 p.m.)

Johnathan gets up from his chair and says, "Leroy, it's time to go." Leroy is working on his math assignment and asks Mrs. Young if he can take his math book with him. Mrs. Young says, "Yes." The two then leave the room. Terri is now in front of the class talking about a trip she has recently taken to Mexico with her family. She demonstrates how a matador fights a bul1. Mrs. Young then came over to me and said, "Can you believe it, two and a half weeks in Mexico! Boy, I sure could use something like that."

By the spring, the novelty of having a couple of black students in the classroom seemed to have worn off a little. Leroy's social attractiveness score dropped from a high of 29 in the fall to a low score of 26 in the spring. By the spring the average social attractiveness score of the two black students was lower than the average social attractiveness score of the white students in the lowest reading group (see Table IX).

As mentioned earlier, the lowest reading group in this classroom was unique in that it was made of all males and was more socially cohesive than the lowest reading groups in the other two classrooms. The data show that the overall social attractiveness of the lowest reading group improved over the course of the school year (see Table IX). Consequently, any negative effect of reading group membership on the social attractiveness of black students appears to have been very slight. 
Fourth Grade

At the beginning of the year there were three black students, Jameson, Sally, and Joey, in this classroom. Joey dropped out of school in November. ${ }^{1}$ Consequently, for most of the year there were only two black students in the room.

In the fall it became clear that the black students were, for the most part, socially unattractive in this classroom. Jameson and Sally respectively had the lowest and second lowest social attractiveness score in the classroom (see Table $X$ ). Both Jameson and Sally were loners. Jameson established no consistent friendships during the whole year. Sally had something of a friendship with Gloria, the other girl in the lowest reading group. However, I often observed her playing alone on the playground. I never observed either Jameson or Sally participate in "Sharing Time." The following account is typical of their withdrawal from classroom activities:

(February 13, 12:20 p.m.).

Mrs. Frank tells the class, "We have not had any reports this week; who wants to give a report?" Most of the students raise their hands. The teacher calls on Henry, a boy from the lowest reading group. Henry talks about a recent crosscountry skiing trip that he had been on and then asks the class, "How many of you have gone cross-country skiing?" About half the students raise their hands. Sally and Jameson are both very withdrawn. Sally is playing with some paper strips and paying no attention to what's going on in

When I asked Joey's teacher why he had stopped coming to Garland she said that she didn't know why. She said that all she knew was that she was "supposed to drop a student from the class 1 ist after they have been absent for eleven straight days." 
TABLE $X$

SOCIAL ATTRACTIVENESS SCORES BY READING GROUP:

FOURTH GRADE

Fall

Group I (highest reading Group)

S1 $M \quad 28$

S2 $\quad M \quad 40$

S3 $F \quad 26$

S4 $\mathrm{F} \quad 37$

$\begin{array}{lll}S 5 & F & 29\end{array}$

S6 $\mathrm{F} \quad 31$ Average $=31.83$

Group II

S7 $\quad M \quad 26$

S8 $\quad M \quad 26$

S9 $M .29$

S10 $\quad M \quad 37$

S11 $F \quad 14$

S12 F 30

$\mathrm{S} 13 \quad \mathrm{M} \quad 28$

S14 M 25

S75 M 36 Average $=29.11$

Group III

S16 M 30

S17 $F \quad 35$

$\begin{array}{lll}S 18 & F & 25\end{array}$

S19 M 26

S20 M 25

S21 M 25

S22 F 40

S23 M 32 Average $=29.75$

Group IV

$\begin{array}{lll}* S 24 & F & 13\end{array}$

$\begin{array}{lll}\mathrm{S} 25 & \mathrm{~F} & 21\end{array}$

S26 M 27

*S27 M 10

**S28 M 26

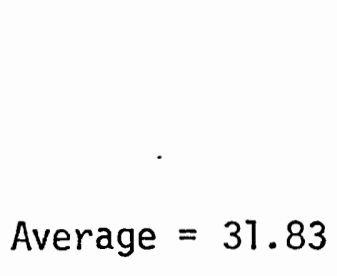

S1 M 35

S2 $M \quad 43$

S3 $F \quad 27$

S4 $F \quad 37$

$\begin{array}{lll}S 5 & F & 19\end{array}$

$\mathrm{S} 6 \quad \mathrm{~F} \quad 36 \quad$ Average $=32.83$

Group II

S8 M 24

S10 $\quad M \quad 34$

S17 $F \quad 6$

S13 M 34

S15 M 29 Average $=25.4$

Group III

S7 $\quad M \quad 31$

S9 $M \quad 21$

S12 $F \quad 31$

S14 M 31

S16 M 29

S17 F 32

S18 F 30

S19 M 28

S20 M 23

S21 M 25

S22 $F \quad 33$

S23 M 40

Average $=29.5$

* Black student

** Black student that dropped out of school in the fall 
class, Jameson is slumped down in his chair with his coat over his head. Jule is now reporting about a book she had just read. She says it's a story about a dog and a cat that become friends.

Sally did not seem to fit in with the rest of the girls in the classroom. Her clothes tended to look sloppy and non-feminine compared to the other girls in the crass. The only other girl she associated with, Gloria, also tended to dress in a sloppy manner:

(May 9, 1:50. p.m.)

Sally is sitting with Gloria now. Gloria is the other girl in the lowest reading group. Sally has her hair in pigtails as usual, and Gloria, who usually wears sloppy jeanoveralls, isn't wearing them today. She's wearing her campfire girl outfit. As I look at them both from the back, Gloria has stringy, dirty hair and a dirty blue campfire girl sweater on, and Sally is wearing a pair of old tennis shoes that are untied.

Jameson was a disciplinary problem in the classroom. On a number of occasions (six that I was aware of) throughout the year, he was sent to the principal's office for disciplinary action. Towards the end of the year, he would get paddled when he was sent to the principal's office. Mrs. Frank's perception of Jameson was that he did not have the ability to do fourth grade work and so he became frustrated and disruptive in class:

(February 11, 3':30.p.m.)

Then we started talking about Jameson and Mrs. Frank said, "You can tell that Jameson always gets frustrated when the class is doing something he can't do." I then asked her if the class ever does something that Jameson can do. Mrs. Frank replied, "Yes, like in the mornings when they're going over multiplication tables, he can repeat those along with the rest of the class. In fact one day he even did a page of fourth grade math, but it was mostly just copying down numbers, it wasn't that difficult. He was real happy after he did that page of math, but the problem is that most of the time the class is doing something way above his head and he gets frustrated and becomes a disciplinary problem." 
Jameson's aggressiveness in the classroom made him socially unattractive to other students.

In the spring, the social attractiveness scores of Sally and. Jameson improved somewhat from what they had been in the fall. However, their average score remained far below the average social attractiveness score of the white students in the lowest reading group (see Table $X$ ): Although the personalities of Jameson and Sally seemed to be paramount in determining their social unattractiveness, their membership in the lowest reading group can be viewed as a contributing factor. Both Sally and Jameson needed access to social activities that would allow them to appear socially attractive.. As brought out earlier, students in the lowest reading group were not allowed to engage in as many different learning-social activities as were other students.

\section{Summary}

The data indicate that reading group membership is not the primary determinant of social attractiveness among black students. In some cases, the personality of the black student clearly was the dominant determinant of social attractiveness. In other cases, the effect of reading ability grouping on social attractiveness was obviously weak or unclear. However, the role that reading group membership played in the social attractiveriess of the black students in these desegregated classrooms was not inconsequential.

Rather than being the primary determinant of social attractiveness among black students, reading group membership acted as an inhibition against an increase in social attractiveness among black students. In 
third grade number one, Joseph's membership in the lowest reading group worked against his becoming socially attractive due to his athletic abilities, In third grade number two, membership in the lowest reading group worked against the persistence of student interest in the personalities of Leroy and Johnathan. In the fourth grade, membership in the lowest reading group restricted the opportunities of Sally and Jameson to engage in socially attractive activities and thus maintained their social unattractiveness. In these cases reading group membership was not the creator of social attractiveness but rather acted as a barrier to the improvement of social attractiveness among black students in three desegregated classrooms.

READING ABILITY GROUPING AND IMAGE OF SUCCESS AMONG BLACK STUDENTS

As mentioned before, the average achievement level at Garland was drastically higher than the achievement levels at the schools from which the black students were bused. The disparity in achievement levels between black and white students was exacerbated by the high level of academic competition present at Garland. The black students who were bused to Garland found themselves in a very competitive atmosphere:

$$
\text { (October 17, 12:40 p.m.) }
$$

The teacher begins to ask questions about what the students have just read in their health books. It seems as though each time the teacher asks a question every student raises his or her hand. Every student has a hand raised now except Johnathan and Leroy. Finally Leroy raises his hand. It seems as though he raised it because everybody else had their hand up and he felt out of place having his down. Mrs. Young calls on Leroy as soon as he raises his hand. She asks him what color his bones are. Leroy doesn't answer. The teacher then calls on another student. 
(12:45 p.m.) The teacher is still asking questions about different parts of the body. Johnathan now raises his hand. Leroy is the only student not raising a hand. The teacher calls on Johnathan. He gives a wrong answer and the teacher calls on another student who answers correctly. Leroy is not raising his hand anymore, he just looks around the room.

(12:50 p.m.) Every time the teacher asks a question, every student except Johnathan and Leroy raises a hand. Some students are sitting on the edge of their chairs and waving both hands. Both Johnathan and Leroy are not raising their hands. Every once in a while, Leroy will raise his hand for a few seconds and then take it down. He doesn't hold it up long enough to get called on. It seems as though he wants to join in with the rest of the class and raise his hand, but he doesn't want to get called on because he doesn't know the answer.

Although the correlations between reading group membership and peer perceived success were not strong in every case (see Table VII), reading group membership tended to be a major contributor to a student's image of success, accounting for 45 percent of the variation in peer perceived success in the fourth grade. Consequently, a close look at the effect of reading group membership on the image of success/failure among black students is in order.

Third Grade Number One

Teacher's Perception. Mrs. Douglas felt that Joseph was capable of doing satisfactory work at the third grade level. However, she also felt that his motivation was such that he would try to avoid work whenever possible:

(October 23, 12:40 p.m.)

About this time Mrs. Douglas walked into the room. I asked her how Joseph was doing. She said, "Joseph is ok, but 
I have to watch him. He's been copying lately. He has the ability to do third grade work, it's just a matter of making sune he does it.

Students' Perception: In terms of peer-perceived success, Joseph fared neither better nor worse than other members of the lowest reading group (see Table XI).. However, his peer-perceived success score was lower in the spring than it had been in the fall, one student referring to him as doing poorly in class. Consequently, it is likely that his membership in the lowest reading group was a contributing factor to his image as a failure. This is perhaps more crucial than it may seem on the surface. As mentioned above, the teacher felt that Joseph was capable of success at the third grade level although his motivation was weak at times. In Tight of this, Joseph's continued membership in the lowest reading group could have weakened further his motivation to Tearn, particularly if his peers began to view his reading group membership as a sign of failure.

Third Grade Number Two

Teacher's Perception. Mrs. Young felt that Johnathan was capable of doing passing work at the third grade level. On the other hand, she said that Leroy shouldn't have been placed in the third grade:

(October 23, 12:10, p.m.)

Mrs. Young then started talking about the black students in her class. She said that Leroy was slipping fast. She mentioned that Leroy shouldn't be in the third grade because he was doing first grade reading and second grade math. She also said that if she had anything to say about it, Leroy would be held back at the end of the year. 
TABLE XI

PEER PERCEIVED SUCCESS SCORES BY READING GROUP:

THIRD GRADE NUMBER ONE

Fal1

Group I (highest reading group)

*ST M 26

S2 M 22

S3 $M \quad 21$

S4 M 23

$\begin{array}{lll}S 5 & F & 27\end{array}$

S6 $F \quad 28$

S7 $F \quad 26$

S8 $\quad M \quad 27$

$\begin{array}{lll}S 9 & F & 37\end{array}$

S10 $F \quad 27$

S17 $F \quad 25$

S12 F 27

S13 M 31

S14 M 25

S15 $F \quad 32$ Average $=26.53$

Group II

S16 M 25

S17 M 23

S18 F 23

* $519 \quad M \quad 26$

S20 M 29

S21 M 25

Group III

\section{S22 M 27}

S23 M 26

**S24 M 26

S25 M 12

S26 F 22
Spring

Group I

S2 $\quad M \quad 25$

S3 $M \quad 25$

S4 M 24

S5 $F \quad 28$

$\begin{array}{lll}S 6 & F & 31\end{array}$

S7 F 30

S8 $\quad M \quad 26$

$\begin{array}{lll}59 & F & 27\end{array}$

S10 F $\cdot 27$

S11 F 25

S12 F, 25

S13 M 31

S14 M 25

S15 $F \quad 31$

S16 M 26 Average $=27.07$

Group II

S17 M 18

$\mathrm{S} 18 \mathrm{~F} \quad 20$

S20 M 30

S21 M 24

S22 M 26

S25 M 13

$\star * * \$ 27 \quad F \quad 26 \quad$ Average $=22.43$

Group III

$\begin{array}{rrrr}S 23 & M & 28 & \\ * * S 24 & M & 24 & \\ S 26 & F & 15 & \text { Average }=22.33\end{array}$

* Student dropped out of school by spring

** Black student (Joseph)

*** New student arriving in January 
I then asked Mrs. Young about how Johnathan was doing. She said that Johnathan was doing "about average." She then clarified her statement by saying that in terms of the rest of the class, Johnathan was doing below average work, but he was able to work on the same material the rest of the class was working.

Students' Perception. In the fall, al1 of the students in the lowest reading group were perceived by other students as "doing poorly" in class (see Table XII)!. An image of failure among students in the lowest reading group seems to have been established early in the school year. Both Leroy and Johnathan contributed heavily to this group image, Leroy having the second lowest peer-perceived success score in the class (see Table XII):

By the spring, Leroy's and Johnathan's peer-perceived success scores had improved. However, they were still perceived as doing poorly in school (see Table XIIH). In the spring members of the lowest reading group continued to be looked upon by their peers as doing poorly in class. Being included in this group contributed to an image of failure for Johnathan and Leroy.

\section{Fourth Grade}

Teacher's Perception. In the fal1 Mrs. Frank expressed concern over the fact that Jameson wasn't achieving up to his potential. She said that he was absent often and when he was in class it was hard to get work out of him. Mrs. Frank felt that he could do fourth grade work, but a high absentee rate and lack of motivation produced poor results. After the first of the year however, Mrs. Frank changed her opinion: 
TABLE XII

PEER PERCEIVED SUCCESS SCORES BY READING GROUP:

THIRD GRADE NUMBER TWO

Fall

Spring

Group I (highest reading group) Group I

S1 $F \quad 29$

$\begin{array}{lll}S 2 & F & 37\end{array}$

S3 $F \quad 27$

S4 F 26

S5 $F \quad 25$

S6 M 26

S7 $F \quad 30$

$\begin{array}{lll}58 & F & 31\end{array}$

S9 $F \quad 31$

S10 M 31

S17 $F \quad 23$ Average $=27.36$

S1 $F \quad 29$

S2 $\mathrm{F} \quad 33$

S3 F 25

S4 F. 28

S5 $F \quad 26$

S6 M 27

S7 $F \quad 26$

S8 $F \quad 30$

S9 $F \quad 34$

S10 $\quad M \quad 31$

S11 $F \quad 24$ Average $=28.45$

Gropu II

Group II

S12 M 25

S13 M 27

S12 M 25

S13 M 25

S14 M 18

S14 M 75

S15 F 25

S15 F 25

S16 F 28

S16 F 26

S17 M 25

S17 M 14

S18 M 28

S18 M 28

S19 F 24

$S 19 F \quad 24$

S20 M. 25 Average $=25$

S20 M 26

$* *$ S26 M 25 Average $=23.3$

Group III

Group III

*S21 M 22

S22 M 22

*S21 M 24

S22 M 24

S23 M. $14 \quad$ Average $=19.8$

S23 M 6

S24 M 24 White Average $=20$

S24 M 28

Average $=21.2$

*S25 M 16 Black Average $=19$

*S25 M 24

White Average $=18.83$

B Tack Average $=24$

* B lack student

** New student 
(January $16,1: 30^{\circ}$ p.m.)

At that time Mrs. Frank came over and started talking to me. She said that Jameson had been very disruptive lately. She then said that the principal had Jameson take an I.Q. test and he (Jameson) scored very low. I asked her what his score was and she said that he had scored within the mentally retarded range. Mrs. Frank went on to say that her expectations of Jameson had been too high and that she wouldn't expect much out of him in the future.

Consequently, from January on, the teacher's perception of Jameson was that he was not capable of success at the fourth grade level.

Mrs: Frank felt that Sally, unlike Jameson, could do fourth grade work. She also felt that Sally lacked motivation:

(October 24, 12:05 p.m.)

I then asked Mrs. Frank how Sally was doing. She said that Sally was doing ok. She then said that, "By ok I mean she's getting by." Mrs. Frank felt that Sally was doing better in her school work than Jameson.

Students' Perception. Other students in the class perceived Jameson and Sally as failures. In the fall they respectively had the lowest and second lowest peer-perceived success score in the class (see Table XIIII). In the Spring Sally's score was a little better but Jameson's was worse. Considering that the average peer-perceived success score for the lowest reading group was way below that of the other reading groups, the black students'identification with the group served as a reference point of failure.

SUMMARY

By the spring, all of the black students in these three classrooms had a negative peer-perceived success score. Everyone of them was 
TABLE XIII

PEER PERCEIVED SUCCESS SCORES BY READING GROUP:

FOURTH GRADE

Fal1

Group I (highest reading group)

S1 $M \quad 30$

S2 $\quad M \quad 42$

S3 $\quad F \quad 29$

S4 $F \quad 35$

S5 $\quad F \quad 24$

S6 $F \quad 27$ Average $=37.17$

S7 $\quad M \quad 22$

S8 $\quad M \quad 25$

S9 $\quad M \quad 24$

S10 $M \quad 27$

S11 F 24

$S 12$ F 26

S13 M 25

S14 M 24

S15 M 26 Average $=24.78$

Group III

$S 17 \quad F \quad 25$

S18 F 25

S19 M 21

S20 M 25

S21 M 25

S22 $F \quad 26$

S23 M 26 Average $=24.75$

Group IV

*S24 F 21

S25 F 24

S26 M 24

*527 M 16

**S28 M 23

Average $=37.17$

Average $=24.78$

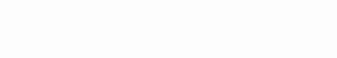

Group II

S16 M 25

* B1ack student

** Black student that dropped out of school in the fall

Black Average $=18.5$
Group I

S1 $\quad M \quad 28$

S2 $\quad M \quad 45$

S3 $F \quad 32$

S4 $F \quad 39$

S5 $\quad F \quad 25$

S6 $\mathrm{F} 27$ Average $=32.67$

Group II

S8 $\quad M \quad 24$

S10 M 26

S11 $F \quad 22$

S.73 $\quad M \quad 26$

S15 M 27 Average $=25$

Group III

S7 $\quad M \quad 24$

S9 M 26

S12 $F \quad 25$

S14 M 22

S16 M 25

S17 F 25

S18 F 24

S19 M 24

S20 M 25

S21 M 23

S22 F 26

S23 M 24 Average $=24.42$

Group IV

*S24 F 23

$\mathrm{S} 25 \mathrm{~F} \quad 19$ Average $=19.5$

$\begin{array}{lrlll}\text { Average }=21.6 & \text { S26 } & \text { M } & 25 & \text { White Average }=22 \\ \text { White Average }=24 & \text { *S27 } & \text { M } & 11 & \text { B Tack Average }=17\end{array}$

$\begin{array}{lrlll}\text { Average }=21.6 & \text { S26 } & \text { M } & 25 & \text { White Average }=22 \\ \text { White Average }=24 & * S 27 & M & 11 & \text { B Tack Average }=17\end{array}$ 
perceived by at least one other students as doing poorly in school. The fact that these black students came to Garland with an average achievement level markedly below that of their white peers obviously had a lot to do with them being perceived as doing poorly. Also, there is no reason to expect that during their first year in a desegregated school they should close the achievement gap between themselves and the white students. However, it is also important to recognize that certain practices in the classroom worked to maintain an image of failure among these five black students and therefore inhibited their development of a successfur image.

Teachers indicated that three of the five black students in these classrooms were capable of being successful students at their grade levels. However, as mentioned above, all five black students had a negative peer-perceived success scores at the end of the year. Their membership in the lowest reading groups contributed to their persistent image of failure. As described earlier, the practice of reading ability grouping in these three classrooms worked to maintain an image of failure among these black students by not giving them equal opportunity to engage in activities that present students as being successful and competent. Moreover, the practice of reading ability grouping placed these five black students in situations where they were constantly identified with other students who were doing poorly in school. 


\section{CHAPTER VIII}

\section{SUMMARY}

One aspect of the process of school desegregation in the three classrooms studied was the practice of reading ability grouping. The practice of reading ability grouping in these classrooms revealed consistent routines. The highest reading groups tended to be instructed first and the lowest reading groups last. In addition, reading ability grouping, as it occurred in these classrooms, involved differential social behavior on the part of teachers and students. Students in the higher reading groups engaged in a greater variety of learning activities and were given a greater opportunity to appear competent than students in the lowest reading groups. The teachers exhibited a differential preference for the various reading groups, preferring to meet with the higher groups first. A7so, the teachers seemed to concentrate more andwere less prone to distraction when working with the higher reading groups than when working with the lowest reading groups. The observed routine and differential behavior associated with reading ability grouping presumably contributed to a situation where reading group membership was associated with a student's social attractiveness and image of success. These consequences were not totally verified by the quantitative data. 
Although the practice of reading ability grouping in the three classrooms under observation revealed distinctive routines and differential social behavior, reading group membership was not strongly correlated to a student's social attractiveness. Whereas, Rist (1974) reported that students in the highest reading groups appeared socialty attractive and students in the lowest reading groups appeared to be socially unattractive, these data failed to indicate a strong relationship between reading group membership and social attractiveness. However, unlike Rist's study, there was not a clear case of social class cleavage between reading groups in these classrooms. Social class was not a salient factor in the composition of reading groups in the three classrooms observed in this study. Consequently, it appears that when the different reading groups do not represent different levels of social class, the relationship between reading group membership and social attractiveness is somewhat tenuous. In the absence of a social class cleavage between reading groups, variables such as gender bias and personality traits can override reading group membership in determining a student's social attractiveness.

Reading group =membership -in the three classrooms "studied wàs more strongly associated with an image of success or failure than with social attractiveness. The structure, composition, routine, and differential behavior associated with the practice of reading ability grouping in these classrooms contributed more to a student's image of competence (among his or her peers) than to his or her social appeal. The relationship between reading group membership and peer-perceived 
success was strongest in the classroom (fourth grade) wherein the size of the highest reading group, along with differential behavior on the part of the teacher and students, produced a situation in which the highest reading group resembled a small social clique.

By the spring, all of the black students in the classrooms studied had a negative peer-perceived success score: Every one of them was perceived by at least one other student as doing poorly in school. The fact that these black students came to Garland with an average achievement level markedly below that of their white peers undoubtedly had much to do with their being perceived as doing poorly. A7so, it may be unreasonable to expect that during their first year in a desegregated school, black students should close the achievement gap between themserves and the white students. However, it is also important to recognize that the practice of reading ability grouping worked to maintain an image of failure among the five black students and thereby inhibited them from developing an image of competence.

If, as was the case in this study, black students are placed in reading groups which deny them equal opportunity to engage in activities that present them as being successfurls and competent; then they, along : with thiti other students in the lower reading group, are more likely to be perceived by classmates as doing poorly in school regardless of their capability for performing at their grade level. All five black students had negative peer-perceived success scores at the end of the year, yet the teachers indicated that three of the five were capable of being successful at their grade level. Under the assumption that peer 
perceptions of faiture operate to reinforce a lack of self confidence in those perceived as failing, reading ability grouping may offer a partial explanation for the failure of school desegregation to achieve higher levels of self confidence among black students. Furthermore, insofar as feelings of self confidence are important for attaining higher achievement levels, the increase in achievement levels among blacks sought through desegregation may also be partially thwarted by reading ability grouping. The absence of such within classroom practices as reading ability grouping may be a necessary condition for successful school desegregation since we have yet to see evidence indicating that increasing achievement levels and greater self confidence among black students has been attained with the use of such practices. 


\section{SELECTED REFERENCES}

A1 1port, Gordon W. 1954. The Nature of Prejudice. Cambridge, Mass.: Addison West tey.

Amir, Yehuda 1969. "Contact Hypothesis in Ethnic Relations," Psychological Butletin, 71(5): 319-342.

Anderson, Louis V. 1967. "The Effects of Desegregation on the Achievement and Personality Pattern of Negro Children," Doctoral

Dissertation, George Peabody College for Teachers. Ann Arbor, Mich.: University Microfilms.

Armor, David J. 1972. "The Evidence on Busing," The Public Interest, 28(summer): $90-126$.

Aronson, Elliot, Nancy Blaney, Jev Sikes, Cookie Stephan, and Matthew Snapp 1975. "The Jigsaw Route to Learning and Liking," Psychology Today, (February): .43-50.

Austin, Mary C., and Morrison Coleman 1963. The First R: The Harvard Report on Reading in Elementary School. New York: Macmillan.

Blalock, Hubert M., Jr. 1972. Social Statistics. New York: McGrawHill Book Company.

Biehler, Robert F. 1954. "Companion Choice Behavior in the Kindergarten," Child Development, 25(1): 45-50.

Bronfenbrenner, Urie 1967. "The Psychological Costs of Quality and Equality in Education," Child Development, 38(4): 909-925.

Carithers, Martha W. 1970. "School Desegregation and Racial Cleavage 1955-1970: A Review of the Literature," Journal of Social Issues, 26(4): $25-47$.

Cohen, Elizabeth G., and Susan Roper 1972. "Modification of Interracial Interaction Disability, "American Sociological Review, 37(6): 643-647.

Esposito, Dominick 1973. "Homogeneous and Heterogeneous Ability Grouping: Principal Findings and Implications for Evaluating and Designing More Effective Educational Environments," Review of Educational Research, 43(2): 163-17.9. 
Findley, Warren G., and Miriam M. Bryan 1975. The Pros and Cons of Ability Grouping. Bloomington, Ind.: Phi Delta Kappa Educational Foundation.

Glaser, Barney G., and Anslem L. Strauss 1967. The Discovery of Grounded Theory: Strategies for Qualitative Research. Chicago: Aldine Publishing Company.

Jencks, Christopher, Marshall Smith, Henry Acland, Mary Jo Bane, David Cohen, Herbert Gintis, Barabara Heyns, and Stephan Michelson 1972. Inequality: A Reassessment of the Effect of Family and Schooling in America. New York: Harper and Row.

Johnson, David A. 1976. "Treating Black Students Like White Students: A Definition of School Integration," Urban Education, 11(1): 95-174.

Kariger, Roger H. 1963. "The Relationship of Grouping to the Sociometric Status of Parents of Seventh Grade Pupils in Three Junior High Schools,". Dissertation Abstracts. East Lansing, Mich.: Michigan State University.

Mackler, Bernard 1969. "Grouping in the Ghetto," Education and Urban Society, 2: 80-95.

McGinley, Pat, and Hugh McGinley 1970. "Reading Groups as Psychological Groups," Journal of Experimental Education, 39(2): 35-42.

Meh1, Robert Frank1in, Jr. 1967. "A Study of the Relationship Between Homogeneous Grouping in the School and the Social Class Structure in an Up-State New York Community," Dissertation Abstracts.

Albany, New York: State University of New York at Albany.

National Education Association 1967. "Administrative Practices in Urban School Districts 1958-59." Washington,.D.C.: National Education Association.

National Education Association 1968. "Ability Grouping Research Summary." Washington, D.C.: National Education Association.

Neugarten, Bernice I. 1946. "Social Class and Friendship Among School Children," American Journal of Sociology, 51(4): 305-313.

Pearl, Arthur 1972. The Atrocity of Education. New York: New Critics Press.

Portland Public School District 1973. "Portland Public Schools: A School by School Report of Basic Skill Test Results and Related School and Community Factors," September. Portland, Oregon: Evaluation Department, Portland Public School District.

Raths, Louis, and E. F. Schweickart 1946. "Social Acceptance Within Interracial School Groups," Educational Research Bulletin, 25(4): 85-90. 
Rist, Ray C. 1974. Urban Education: Factory for Failure. Cambridge, Mass.: The MIT Press:

Schafer, Walter E., and Carol 01exa 1971. 'Tracking and Educational Opportunity. Scranton, Penn.: Chand7er Publishing Company.

Smith, Louis M., and William Geoffrey 1968.". The Complexities of the Urban Classroom: New York: Rinehart and Winston.

Smith, Marscha11 S. 797.7. "Equality of Educational Opportunity: The Basic Findings Reconsidered,". On Equality of Educational Opportunity, Editors, F. Mosteller and D. P. Moynihan. New York: Random House.

St. John, Nancy 1975. School Desegregation Outcomes for Children. New York: John witey and Sons.

Teplin, Linda A. 1972. "A Study of Sociometric Choice and Rejection Behavior Among Secually, Racially, and Ethnically Integrated Groups of Elementary School and High School Students." Evanston, 117 inois: Department of Sociology, Northwestern University (unpublished).

United States Civil Rights Commission 1969. Civil Rights U.S.A.: Public Schools, Cities in the North and West. Washington, D.C.: United States Government Printing Office.

Wilson, Robert M., and Jerily K. Ribovich 1973. "Ability Grouping? Stop and Reconsider!" Reading World, 13(2): 84-91. 
APPENDIX A

RAW SCORES USED TO COMPUTE

CORRELATION COEFFICIENTS

\begin{tabular}{|c|c|c|c|}
\hline Classroom & $\begin{array}{l}\text { Reading } \\
\text { Group }\end{array}$ & $\begin{array}{c}\text { Social } \\
\text { Attractiveness }\end{array}$ & $\begin{array}{c}\text { Peer-Perceived } \\
\text { Success }\end{array}$ \\
\hline & & Fall $\quad$ Spring & Fal1 Spring \\
\hline
\end{tabular}

$\begin{array}{llllllll}\text { S1 } & \text { M } & \text { Third \#1 } & 4 & 23 & 24 & 22 & 25 \\ \text { S2 } & \text { M } & \text { Third \#1 } & 4 & 25 & 19 & 21 & 25 \\ \text { S3 } & \text { M } & \text { Third \#1 } & 4 & 28 & 25 & 23 & 24 \\ \text { S4 } & \text { F } & \text { Third \#1 } & 4 & 25 & 24 & 27 & 28 \\ \text { S5 } & \text { F } & \text { Third \#1 } & 4 & 27 & 37 & 28 & 31 \\ \text { S6 } & \text { F } & \text { Third \#1 } & 4 & 35 & 30 & 26 & 30 \\ \text { S7 } & \text { M } & \text { Third \#1 } & 4 & 29 & 29 & 27 & 26 \\ \text { S8 } & \text { F } & \text { Third \#1 } & 4 & 32 & 26 & 31 & 27 \\ \text { S9 } & \text { F } & \text { Third \#1 } & 4 & 34 & 38 & 27 & 27 \\ \text { S10 } & \text { F } & \text { Third \#1 } & 4 & 28 & 28 & 25 & 25 \\ \text { S11 } & \text { F } & \text { Third \#1 } & 4 & 30 & 29 & 27 & 25 \\ \text { S12 } & \text { M } & \text { Third \#1 } & 4 & 49 & 49 & 31 & 31 \\ \text { S13 } & \text { M } & \text { Third \#1 } & 4 & 28 & 28 & 25 & 25 \\ \text { S14 } & \text { F } & \text { Third \#1 } & 4 & 23 & 25 & 32 & 31 \\ \text { S15 } & \text { F } & \text { Third \#2 } & 4 & 36 & 35 & 29 & 29 \\ \text { S16 } & \text { F } & \text { Third \#2 } & 4 & 24 & 4 & 37 & 33 \\ \text { S17 } & \text { F } & \text { Third \#2 } & 4 & 31 & 32 & 27 & 25 \\ \text { S18 } & \text { F } & \text { Third \#2 } & 4 & 30 & 30 & 26 & 28 \\ \text { S19 } & \text { F } & \text { Third \#2 } & 4 & 34 & 36 & 25 & 26 \\ \text { S20 } & \text { M } & \text { Third \#2 } & 4 & 22 & 32 & 26 & 27 \\ \text { S21 } & \text { F } & \text { Third \#2 } & 4 & 32 & 28 & 30 & 26 \\ \text { S22 } & \text { F } & \text { Third \#2 } & 4 & 29 & 35 & 26 & 30 \\ \text { S23 } & \text { F } & \text { Third \#2 } & 4 & 32 & 24 & 36 & 34 \\ \text { S24 } & \text { M } & \text { Third \#2 } & 4 & 36 & 32 & 26 & 31 \\ \text { S25 } & \text { F } & \text { Third \#2 } & 4 & 29 & 26 & 23 & 24 \\ \text { S26 } & \text { M } & \text { Fourth } & 4 & 28 & 34 & 30 & 28 \\ \text { S27 } & \text { M } & \text { Fourth } & 4 & 40 & 43 & 42 & 45 \\ \text { S28 } & \text { F } & \text { Fourth } & 4 & 26 & 27 & 29 & 32 \\ \text { S29 } & \text { F } & \text { Fourth } & 4 & 37 & 37 & 35 & 39 \\ \text { S30 } & \text { F } & \text { Fourth } & 4 & 29 & 19 & 24 & 25 \\ \text { S31 } & \text { F } & \text { Fourth } & 4 & 31 & 36 & 27 & 27 \\ \text { S32 } & \text { M } & \text { Fourth } & 3 & 26 & 24 & 25 & 24 \\ \text { S33 } & \text { M } & \text { Fourth } & 3 & 37 & 34 & 24 & 20 \\ \text { S34 } & \text { F } & \text { Fourth } & 3 & 14 & 6 & 24 & 22 \\ \text { S35 } & \text { M } & \text { Fourth } & 3 & 28 & 34 & 25 & 26\end{array}$


APPENDIX A

RAW SCORES USED TO COMPUTE CORRELATION COEFFICIENTS (continued)

\begin{tabular}{|c|c|c|c|c|c|c|c|}
\hline & Sex & Classroom & $\begin{array}{l}\text { Reading } \\
\text { Groüp }\end{array}$ & Attr & $\begin{array}{l}\text { ial } \\
\text { iveness }\end{array}$ & $\begin{array}{l}\text { Peer- } \\
\quad \text { Su } \\
\end{array}$ & $\begin{array}{l}\text { rceived } \\
\text { ess }\end{array}$ \\
\hline & & & & Fall & Spring & Fall & Spring \\
\hline S36 & M & Fourth & 3 & 36 & 29 & 26 & 27 \\
\hline S37 & M & Third \# 1 & 2.5 & 25 & 24 & 23 & 18 \\
\hline S38 & $\mathrm{F}$ & Third \#1 & 2.5 & 27 & 14 & 23 & 20 \\
\hline S39 & M & Third \#1 & 2.5 & 40 & 43 & 29 & 30 \\
\hline$S 40$ & M & Third \#1 & 2.5 & 32 & 29 & 25 & 24 \\
\hline S41 & M & Third \#2 & 2.5 & 23 & 27 & 25 & 25 \\
\hline S42 & M & Third \#2 & 2.5 & 29 & 37 & 27 & 25 \\
\hline $\mathrm{S} 43$ & M & Third \#2 & 2.5 & 25 & 23 & 18 & 15 \\
\hline S44 & $\mathrm{F}$ & Third \#2 & 2.5 & 28 & 30 & 25 & 25 \\
\hline S45 & $\mathrm{F}$ & Third \#2 & 2.5 & 22 & 29 & 28 & 26 \\
\hline S46 & $\mathrm{F}$ & Third \#2 & 2.5 & 25 & 24 & 25 & 14 \\
\hline 547 & M & Third \#2 & 2.5 & 38 & 28 & 28 & 28 \\
\hline$S 48$ & $F$ & Third \#2 & 2.5 & 23 & 27 & 25 & 24 \\
\hline S49 & M & Third \#2 & 2.5 & 32 & 29 & 25 & 26 \\
\hline S50 & M & Fourth & 2 & 30 & 29 & 25 & 25 \\
\hline S51 & F & Fourth & 2 & 35 & 32 & 25 & 25 \\
\hline S52 & $\mathrm{F}$ & Fourth & 2 & 25 & 30 & 25 & 24 \\
\hline S53 & M & Fourth & 2 & 26 & 28 & 21 & 24 \\
\hline S54 & $M$ & Fourth & 2 & 25 & 23 & 25 & 25 \\
\hline S55 & M & Fourth & 2 & 25 & 25 & 25 & 23 \\
\hline S56 & $\mathrm{F}$ & Fourth & 2 & 40 & 33 & 26 & 26 \\
\hline S57 & M & Fourth & 2 & 32 & 40 & 26 & 24 \\
\hline S58 & M & Third \#1 & 1 & 32 & 30 & 26 & 28 \\
\hline S59 & M & Third \#! & 1 & 25 & 28 & 26 & 24 \\
\hline$S 60$ & $\mathrm{~F}$ & Third \#1 & $i$ & 11 & 11 & 22 & 12 \\
\hline S61 & $M$ & Third \#2 & 1 & 27 & 27 & 22 & 24 \\
\hline S62 & M & Third \#2 & 1 & 18 & 29 & 22 & 24 \\
\hline S63 & M & Third \#2 & $i$ & 12 & 10 & 14 & 6 \\
\hline S64 & M & Third \#2 & $i$ & 35 & 42 & 16 & 28 \\
\hline S65 & M & Third \#2 & 1 & 29 & 26 & 24 & 24 \\
\hline S66 & $F$ & Fourth & 1 & 13 & 19 & $2 i$ & 23 \\
\hline G & $\mathrm{F}$ & Fourth & 1 & 21 & 19 & 24 & 19 \\
\hline S68 & M & Fourth & 1 & 27 & 30 & 24 & 25 \\
\hline S69 & M & Fourth & 1 & 10 & 13 & 16 & 11 \\
\hline
\end{tabular}




\section{APPENDIX B}

\section{SOCIOMETRIC QUESTIONNAIRE}

1. If you had a chance to sit by any student in the classroom, who would by your first choice? Second choice? Third choice?

2. Is there any student in the classroom that you particularly do not want to sit next to? Anyone else?

3. Can you name for me someone who you think is doing very well in class? Anyone else?

4. Can you name for me someone who you think is doing very poorly in class? Anyone else? 